\title{
RENDSZERIGAZOLÁS ÉS RENDSZERKRITIKA ${ }^{1}$
}

\section{HUNYADY GYÖRGY}

\author{
Eötvös Loránd Tudományegyetem Pedagógiai és Pszichológiai Kar \\ E-mail: hunyady.gyorgy@ppk.elte.hu
}

Beérkezett: 2018. január 8. - Elfogadva: 2018. január 22.

Online megjelenés: 2018. május 17.

\begin{abstract}
A társadalmi rendszert övezô, leképezô és alakitó megismeréssel és érzelmekkel foglalkozó alapvetố szociálpszichológiai elméletek egyik kitüntetett tárgyköre a rendszerigazolás, a hierarchia alján elhelyezkedô emberek, tömegek aktív támogató attitúdje, a számukra elónytelen viszonyok legitimálása. John Jost kimunkált elméletét a haladott világban gyüjtött gazdag tapasztalati anyag támogatja. Ettôl eltéröen azonban a posztkommunista régióban (jelesen Magyarországon is) a rendszerigazolás mellett a közgondolkodásban megjelenik, sôt hosszabb távon is alkalmasint felül tud kerekedni a rendszerkritika. Az utóbbi másfél évtizedben (többek között 8 országos reprezentatív mintán) végzett sztereotípia-, attitüd-, érték-és társadalmiközérzet-vizsgálataink egzakt módon leírják a rendszerkritika és a rendszerigazolás ambivalenciáját: a mai magyar közgondolkodásban az alapvetốn a szociális biztonság hiányából fakadó elégedetlenséget, morális társadalomkritikát, a demokrácia fokozott igényét, szemben a gazdasági-politikai viszonyok méltatásával, a hatalomösszpontositás támogatásával. Jellemzi a magyar közállapotokat, hogy a domináns rendszerkritika a jövôre nézve pesszimizmussal, a szubdomináns rendszerigazolás optimizmussal társul. A nemzetközi trendek különbségeinek történeti-kulturális értelmezésén túl a tanulmány ajánlásokat fogalmaz meg a rendszerigazolás elméletének továbbépitésére (a rendszerattitüdök ambivalenciájának, a rendszerek különbözöségének, a rendszerképek kontextusának és a kilátások észlelt valószinúségének szentelt figyelemmel). E kutatások a társadalmi nézetekbôl kiolvasható közérzet vizsgálatára 7 alskálát tartalmazó, úgynevezett kontraszelekciós skálarendszert, illetve a demokráciafelfogás összetevôit mérô 3 skálát vezettek be és alkalmaztak.
\end{abstract}

Kulcsszavak: rendszerigazolás, rendszerkritika, kontraszelekció-skála, demokráciaattitüd mérése, társadalmi közérzet Magyarországon, rendszerattitüdök történeti kontextusa

1 A tanulmány szakmailag kimunkáltabb, jegyzetekkel és irodalomjegyzékkel ellátott változata a szerzô 2017. évi Magyar Tudomány Ünnepén „Rendszerigazolás és rendszerkritika” címen a Magyar Tudományos Akadémián elhangzott elôadásának. 
Vegyük fel az idôk fonalát. 2002-ben elhangzott székfoglaló elôadásomban vezettem be a szakmai szóhasználatba a kontraszelekció-élmény fogalmát (Hunyady 2002). Magyar embernek nem kell magyaráznom, hogy a köztudatban alkalmasint élhet és nálunk bizony elterjedt egy olyan társadalomkép, amely szerint a státus és az erény reciprok viszonyban áll egymással: eszerint az jut többre, aki amorális, ezzel esetleg kipótolva vagy megtetézve a tehetség és szorgalom hiányát is.

A pszichológiai okfejtésekben gyakran megbúvik egy jellegzetes kettôsség, arról beszélünk, hogy az emberek mit éreznek és gondolnak, nem állítva, de megengedve, hogy élményviláguknak van valóságfedezete, esetleg élményeik teremtik a viszonyok valóságát. E kettôsség a kontraszelekcióról szólván bennem is élt: miközben a piacgazdasági demokráciák nyugati világában honos meritokratikus társadalomképtôl élesen elütố modellbe ütköztem, és azt elemeztem a hazai közfelfogásban, nem mondtam és nem gondoltam, hogy ez itt teljesen alaptalan torzkép lenne a valóságról. Sót, a székfoglaló elốtt évekkel már foglalkoztam azzal, hogy a magyar történetben milyen mechanizmusok gátolták, szürték és rombolták a tehetségek kiemelkedését, különös tekintettel a kimúlni oly nehezen képes feudális különbségtételre urak és szolgák között, majd a gyökeret verni képtelen kollektivizmus türelmetlenségére a kiválóság jeleivel és képviselôivel szemben (Hunyady, 2000). Meglehet, ezek tényszerú kapaszkodói a szkepszisnek az intellektuális és morális értékek érvényesülésével kapcsolatban, hosszabb távra kitekintô elemzésük arra mindenképpen jó volt, hogy eloszlassa azt a félreértést, hogy a kontraszelekció élményét csak a rendszerváltástól vagy a székfoglalót is felölelô 1998-2002-es kormányzati periódus belviszonyaiból eredeztetném.

Azt a feltételezést, hogy lehet valóságmagva a köztudatban megjelenô kontraszelekció-élménynek, a maga szellemes módján megtámogatta a korán elhunyt kiváló társadalomfilozófus, Bence György a székfoglalóhoz füzött azon kommentárjával: lehetnek és vannak rendszerek, amelyek tényleges kontraszelekció nélkül nem is léteznének és maradtak volna fenn. Bármikor bármi legyen is a valóságalapja, a kontraszelekció-élmény mindenképpen kritikai értékelés a társadalmi viszonyokról, és szemben áll ezen viszonyok pozitív megítélésével és érvelô támogatásával. Mai elôadásom tárgya tulajdonképpen ez: a társadalom viszonyrendszeréhez való pozitív/negatív értékelô viszonyulás: az emberek hogyan - mennyire pozitívan, mennyire negatívan - viszonyulnak ahhoz a társadalmi viszonyrendszerhez, melyben élnek, amely körbeöleli és ebben az ölelésben erôsen tartja is ôket. Gondolhatnánk, hogy ez a szociálpszichológia felettébb hagyományos problémája, amellyel immár évszázados történetében sokoldalúan és behatóan foglalkozott. Azonban e tudomány hosszú-hosszú idôn át személyek egymásra hatásáról, a véleményalakulásról és a szociális információkezelésrôl szólt, és még az 1990-es évek hajnalán is szinte váteszi jóslat volt William McGuire egyedülálló politikai pszichológiai szintézisének záró bekezdése (McGuire, 1998), mely szerint e tudományterület elkövetkezendó (szerinte negyedik) korszaka a nagy társadalmi csoportok viszonyrendszerének pszichológiai tárgyalása lesz. A jóslat azonban bevált, s azóta e tárgyban - számos parciális megközelítés mellett - három átfogó elméletet tartunk számon (Hunyady, 2005; Political Psychology 25(6)). Ezek egyike az egyén csoportazonosulásával, saját csoportjának részrehajló felértékelésével foglalkozik: ez a szociális 

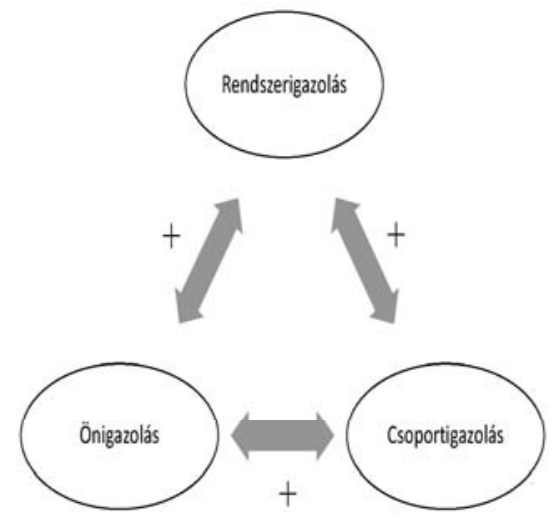
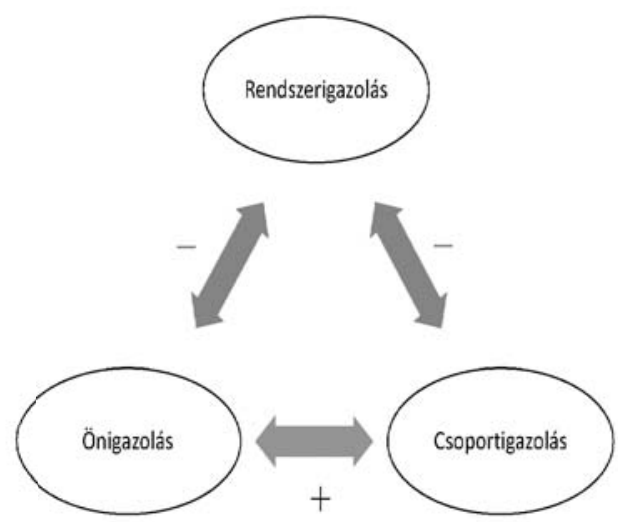

1. ábra. A három igazolás viszonya (Jost, 2003a)

identitás sokfelé ágazó elmélete (Tajfel, 1981; Tajfel és Turner, 1979; Turner, 1987; Csepeli, 1980), amely a szaktudomány múvelésében szinte egyetlen közös európai és amerikai gondolati építkezés. A másik a társadalom hierarchikus viszonyainak fenntartásával, az uralomra töró és az uralmat gyakorló csoportok aktivitásával foglalkozik (Sidanius és Prato, 1998, 2005). A szociális dominancia ezen elmélete kritikusan tárja fel a hierarchikus rend haszonélvezôinek eszköztárát, így az ún. legitimációs mítoszokat, de minden eredendô szándék ellenére a hatalmi hierarchia célszerûségének és elkerülhetetlenségének bizonygatásával hovatovább maga is evolúciós mítoszt sugall. A harmadik elmélet, amely e tárgykörben 1994-ben született John Jost és kiváló tutora, Mahzarin Banaji tanulmányával bevezette és nevében hordozza a rendszerigazolás fogalmát (Jost és Banaji, 1999). Az ez alkalommal (is) kitüntetett figyelmünket élvezô elmélet elüt a másik kettôtôl (Jost, 2003c): a szociális identitás tanával ellentétben állítja, hogy van olyan társadalmi-pszichológiai erô, amely felülírja a saját csoport, társadalmi kategória preferenciáját.

A szociális dominancia megközelítéstôl eltérôen viszont nem az uralkodó csoportok mentalitásával és manipulációjával foglalkozik, hanem az alávetett ellenoldallal, amely jól felfogott önérdeke ellenére is betagozódik a társadalmi hierarchiába, elfogadja a hatalom birtokosainak kiváltságait és kiválóságát, így maga is a rendszer tevékeny közremúködôje és támogatója lesz. (Az elmélet fejlôdéséról ld. Jost, Guermandi, Mosso, Kivetz, Pelham és Burgess, 2001; Jost, 2003a; Jost, Banaji és Nosek, 2004; van der Toorn és Jost, 2014; Jost, Burgess és Mosso, 2003; Jost és van der Toorn, 2012.)

Jost gondolati kiindulópontja az volt, hogy az alávetett, hátrányt szenvedô csoportok rendszerint magukkal szemben a felettük állókat preferálják, amint ez a körükben (is) elterjedt sztereotípiákból kiolvasható. Ennek a preferenciának legkülönbözóbb példáit változatos kontextusban gazdagon demonstrálja (Jost, 2003b). Vajon szerinte mi írja felül az önérték, önérdek, illetve a saját csoport értéke s érdeke kinyilvánításá- 
nak és érvényesítésének logikáját (amelyek viszonyában ugyan megbújhat konfliktus, de amelyek alapvetôen egy irányba hatnak).

A megoldás kulcsa Jost (és szerzôtársai) szerint az, hogy a társadalmi rend fenntartása és képviselete fontos a hierarchia alján lévôk számára: ez kell a viszonyok biztonságot kölcsönzó átlátásához, ez kell a félelmek és kétségek nyomasztó érzéseinek elkerüléséhez, valamint ez adja meg a széleskörú egyetértés ugyancsak megnyugtató és támogató élményét (Jost, Liviatan, van der Toorn, Ledgerwood, Mandisodza és Nosek, 2010; Hennes, Nam, Stern és Jost, 2012; Jost, Ledgerwood és Hardin 2008). E hármas - episztemológiai, egzisztenciális és kapcsolati - motiváció indítja ôket arra, hogy igazságosnak ismerjék el a rendszer hierarchikus viszonyait és benne saját helyüket, ily módon a szó egyetemes értelmében legitimizálják e rendszert, ami (mint Machiavelli óta számon tartjuk) nélkülözhetetlen feltétele az uralmi rendszer olajozott múködésének. ${ }^{2}$ Ezen magyarázathoz szervesen hozzátartozik és sokrétú empirikus alátámasztást nyer számos felismerés. Így:

1. A rendszerigazolás letéteményesei (miután alávetett helyzetük disszonanciáját magukban eltemették) nagyobb belsô harmóniában élnek, elégedettebbek, lelki-testi egészségük is viszonylag kedvezóen alakul (ami a szerzôk szerint nem zárja ki, hogy egyesek vagy sokan társadalmi helyzetük elfojtott disszonanciájának hosszabb távon kárát lássák) (Jost és Hunyady, 2002, 2005).

2. A fölé- és alárendeltség sztereotípiái nemcsak a viselkedés felszínén mutatkoznak körükben, konformista engedményként vagy tudatos önkontroll alatt, hanem a tudattalan folyamatokról és struktúrákról árulkodó reakcióikból (egészen pontosan a reakciók idejéból) is kiolvashatóak mint rejtózó (implicit) megítélések és értékelések (Jost, 2001; Jost, Pelham és Carvallo, 2002; Jost, Banaji és Nosek, 2004; Jost, Pietrzak, Liviatan, Mandisodza és Napier, 2007; Lane és Jost, 2011).

3. Szinte perdöntô jelentôségú, hogy a csoportok rendezett viszonyát, a társadalom rendjét veszélyeztetố információk (adagolják ezeket akár játékosnak mondható kísérleti instrukciókban, vagy diktálják óket valóságos megrázkódtatásokat tanúsító vagy kiváltó tényszerú híradások) felerôsitik a rendszer igazságosságába és legitimitásába vetett hitet, a hierarchia magasabb és alacsonyabb szintjei között látni vélt értékbeli különbségeket (Napier, Mandisodza, Andersen és Jost 2006; Bonanno és Jost 2006; Jost, Napier, Thorisdottir, Gosling, Palfai és Ostafin 2007; Wakslak, Jost és Bauer 2011; Thorisdottir és Jost 2011; Jost és Napier 2012).

4. Miközben a társadalmi kategóriák sztereotip jellemzése a maga értékelô töltetével kifejezi és erôsíti a rendszer hierarchikus viszonyait, tartalma betölthet egy öszszebékítô, látszólag egyenlősitô funkciót is a társadalomképben. Jost (Fiske és Glück gender-sztereotípia elemzésével összhangban) úgy látja, visszatérô, modellszerú a sztereotípiák tartalmi mintázatában, hogy míg a magasabb státusúak jellemzésében

\footnotetext{
A rendszerigazolás elméletének egyik legföbb jellegzetessége és érdeme, hogy széles ívú összefüggést tételezett fel és mutatott be a csoportsztereotípiák tartalma és a társadalmi viszonyok igazságosságának és legitimitásának megítélése között. Perdöntően hozzájárult ahhoz, hogy ez utóbbi témakör a szociálpszichológia nemzetközi szakirodalmának egyik tematikus gócpontja lett Jost és Major 2001-es kötete (2001a) és különösen tanulmányuk (2001b). Továbbá: Blasi és Jost, 2006; Tyler és Jost, 2007; Jost, Kay és Thorisdottir, 2009; Gaucher és Jost, 2011; van der Toorn, Tyler és Jost, 2011; Jost és Kay, 2012; Jost, Hawkins, Nosek, Hennes, Stern, Gosling és Graham, 2014.
} 
az erôt adó és hatékonyságot tükrözô vonásokat emelik ki, addig az alacsonyabb státusúaknak - mintegy jó szándékúan - a szociális készségeit és morális erényeit ismerik el (Kay és Jost, 2003; Jost, Kivetz, Rubini, Guermandi és Mosso, 2005; Jost és Kay, 2005; Kay, Jost, Mandisodza, Sherman, Petrocelli és Johnson, 2007; Kay, Czaplinski és Jost, 2009; Napier, Thorisdottir és Jost, 2010; Oldmeadow és Fiske, 2007).

5. A társadalom magaslatait elfoglaló csoportok esetében értelemszerúnek tûnik, hogy a viszonyok igazolására egyéni és csoportszempontból is motiváltak. A rendszerigazolás motivációja viszont azt a látszólag/láthatóan irracionális partállást is magyarázza, hogy az alávetett csoportok miért igazolják a rájuk telepedő, óket nyomasztó társadalmi hierarchiát. ${ }^{3}$ Felmerült és alkalmasint bizonyíthatónak tûnik, hogy minél elônytelenebb egy társadalmi kategória helyzete, annál inkább elismeri és támogatja a hierarchikus berendezkedést. De ha ez nem is bizonyulna teljes körú, lineáris összefüggésnek, a munkások tömeges tekintélyelvúségének sokszorosan regisztrált jelensége felfogható, mint egy ilyen tendencia tanúbizonysága (Jost, 2017b).

6. A rendszerigazolással mint motivált megismeréssel nemcsak analóg módon rokonítható, hanem Jost és Kruglanski szerint lényegi tartalmi átfedésben áll a konzervatív ideológia (Jost, Kruglanski és Simon, 1999; Jost, Glaser, Kruglanski és Sulloway, 2003; Napier és Jost, 2008a). Az az erôs előfeltevésük, hogy a társadalom fejlôdése hosszú távon végsố soron az egyenlôtlenségek leküzdése irányába mutat, ennek a folyamatnak vannak úttörôi és kerékkötôi, szerintük a demokrácia kereteiben ez utóbbi szerepet töltik be a konzervatívok, akik a különbségek fenntartása mellett érvelnek és szállnak síkra.

7. A rendszerigazolás általában és a konzervativizmus sajátosan mind közrejátszanak abban, hogy érzékeljük és felismerjük, hogy a társadalmi viszonyokat értékeló ideológiák járják át a közgondolkodást. Idôszakos látszat volt a világrendszerek közötti feszültségek enyhülése, az ún. békés egymás mellett élés idején, hogy az ideológiák kora véget ért, Jost szerint „vége van az ideológiák végének” (Jost, 2006; Jost, Nosek és Gosling, 2008; Jost, Federico és Napier, 2009, 2013; Lavine, Jost és Lodge, 2014; Jost, 2017a; Jost, Kay és Thorisdottir, 2009).

8. A konzervatív eszmerendszerre bizonyos személyiségjellemzók hajlamosítanak, mint ahogy úgymond liberális ellenpólusának is vannak pszichológiai jellemzôi. Ezen eltérések a köznapi magatartásban és kialakított környezetben is kiütköznek (Carney, Jost, Gosling és Potter, 2008; Stern, West, Jost és Rule, 2014; Sterling, Jost és Pennycook, 2016; van der Toorn, Nail, Liviatan és Jost, 2014) - amint közfigyelmet és többek ingerült reakcióját kiváltó írásukban Jost és munkatársai ezt empirikus alapon illusztrálták. (Az ellenoldalt itt ugyan címkézhetik liberálisnak, de épp ideológiai vonatkozásban ez a két tábor nem minden téren áll egymással szemben: a gazdasági különbségek létjogának és értéktartalmának elismerése lényegi ponton közösséget is teremt közöttük. Jost, Blount, Pfeffer és Hunyady, 2003)

Az elmélet centrális gondolata, hogy a rendszerigazolás a társadalmi egyenlôtlenség elfogadását szolgálja: Jost, Pelham, Sheldon és Sullivan, 2003; Kay, Jost, Mandisodza, Sherman, Petrocelli és Johnson, 2007; Jost, Wakslak és Tyler, 2008; Costa-Lopes, Dovidio, Pereira és Jost, 2013; Callan, Kay és Dawtry, 2014; Jost, Gaucher és Stern, 2014; van der Toorn, Feinberg, Jost, Kay, Tyler, Willer és Wilmuth, 2015; Pliskin, Yudkin, Jost és Trope, in press. 
A vázlatosan bemutatott gondolatrendszer és a világszerte gyújtött tekintélyes tapasztalati tényanyag tükrözi, hogy a rendszerigazolás elmélete egy integratív és nagy kisugárzású szellemi vállalkozás. Érintôlegesen sem lehet felsorolni, hogy hány és hányféle felfogás között ver hidat és hozza ôket közös nevezôre. ${ }^{4}$ Természetes, hogy egy ilyen nagy vonzerejú és expanzív gondolati irány számos ponton jelent intellektuális kihívást és ösztönzően hat ellenvélemények kinyilvánítására és kimunkálására. ${ }^{5}$

A rendszerigazolás elmélete fontos tudománytörténeti előrelépés, amint megragadja az egyénnek a társadalmi viszonyrendszer egészére irányuló felfogását és attitúdjét, ami aztán összegezve a rendszer érzelmi elfogadottságának és legitimitást kölcsönzó igazolásának társadalmi összképét nyújtja.

Számunkra ezen elmélet különösen sokat mond, ha akár itthon az irracionálisnak túnó rendszertámogatás racionális magyarázatát keressük, különös tekintettel annak tömeges jelentkezésére (amelynek volumenét az ún. csoportattribúciós hiba csapdájába esve talán el is túlozzuk - Allison, Mackie és Messick, 1999). E nézópontból paradox, hogy Jost és munkatársa, Cichocka a régióban (és annak ékes példájaként Magyarországon) szokatlanul erôtlennek minôsítik a rendszerigazolás jelentkezését és kirívóan túlnyomónak találják a rendszerrel szembeni kritikai atmoszférát (Chichoka és Jost, 2014). Jóllehet kiindulópontjuk az volt, hogy a rendszerigazolás a hierarchikus viszonyokat elfedő „hamis tudat”, az ellentétébe való átfordulást mégsem a társadalmi tisztánlátás méltányolható jelentkezésének tekintik, hanem valamiféle posztkommunista utóhatásnak, amely egyfelôl beágyazódik a lokális panaszkultúrába, másfelól tanult tehetetlenségre vezet politikai téren. ${ }^{6}$ Nem vitás, hogy az úgynevezett kommunizmus mély és ellentmondásos nyomokat hagyott a régió társadalmaiban. A szocializmus eszméit kompromittálva Marxhoz, Leninhez és Sztálinhoz köthetố három dogmát hirdetett és követett: a munkásosztály történeti megváltó szerepét, az osztályuralmat képviseló és

4 Nyilvánvaló a gondolati kapcsolódás a személyes és társadalmi helyzet idealizálását tárgyaló elméletekkel, lásd igaz világba vetett hit, a protestáns munkaetika-felfogás, meritokratikus társadalomkép és így tovább. A sztereotípiák funkcióinak elemzése - különös tekintettel a társadalom életében játszott szerepükre - átfedô megfontolásokat eredményez. A társas-társadalmi összehasonlítás sokat tárgyalt mechanizmusai és elméletei rendre mind relevánsak a rendszerigazolás nézôpontjából, különös tekintettel a viszonyok igazságosságának megítélésére. Mint ahogy a kognitív disszonancia elméletének relevanciájához sem fér kétség, ha annak érvényességi körét az elkötelezô tettekrôl kiterjesztjük az elfoglalt helyzetek igazolására is.

A rendszerigazolás vizsgálata során az implikált sztereotípiák és attitúdök felderítése - például - fontos szerephez jutott, ennek megfelelôen elérte és kutatóit sarkos állásfoglalásra késztette az „implicit bias” módszertani vitája lásd Jost, Rudman, Blair, Carney, Dasgupta, Glaser és Hardin, 2009a, 2009b; Jost, Federico és Napier, 2009.

A rendszerigazolási elmélet előfeltevéseinek kibontására, árnyalására és kikerekítésére tett továbbfejlesztési kísérletek is járhatnak természetesen gondolati súrlódással és polémikus eredményekkel, amint ezt példázhatja Brandt, 2013; Sibley és Duckitt, 2010; Son Hing, Bobocel, Zanna, Garcia, Gee és Orazietti, 2011. A viszonyok igazságosságának és legitimitásának elemzése során megkülönböztetett jelentôségre tesz szert, hogy a különbözó elméletek az erkölcsi megítélést honnan eredeztetik és milyen szerepet tulajdonítanak neki Haidt 2001; Kugler, Jost és Noorbaloochi 2014.

6 Cichocka és Jost, 2014, különösen 16-19. A gondolatmenet további kibontása, hogy a rendszerigazolás bizonyos szintje a feltétele az aktív közéleti-politikai részvételnek Cichocka, Górska, Jost, Sutton és Bilewicz, 2017. Vö a korábbiakból még Jost, Chaikalis-Petritsis, Abrams, Sidanius, van der Toorn és Bratt, 2012. 
kiváltó pártdiktatúrát és a bolsevik világhatalom birodalmi politikájának szolgálatát és kultuszát. Ez próbára tette a régió lakóinak életképességet és tartását. Többek között olyan felejthetetlen eredménnyel, mint a nagyhatalmi alkuk ellenére fellobbanó és a világ közvéleményét újrahangoló magyar 56, vagy a bolsevik uralom alapjait munkásmozgalmi eszközökkel és szívóssággal kikezdô lengyel Szolidaritás. (Ezek kezdeményezô ereje, emberi tétje, morális alapja épp oly megkérdôjelezhetetlen, mint az amerikai demokrácia dicsôsége, a vietnámi háború ellenes korszakos fellépés.) A rendszerigazolási elmélet érvényesülését és érvényességét vizsgálva természetesen kitüntetett figyelmet érdemelnek a régiók közelebbi s távolabbi történeti sajátosságai.

A rendszerigazolás elméletének mondanivalója egyetemes, szisztematikusan gyújtött tapasztalati alapja a haladott világra terjed ki, gondolati fogantatása ideje és helye az ezredforduló Amerikája. Az elmélet történeti kötöttsége megnyilvánul abban, hogy a) A történeti fejlôdés mozgásirányát explicit módon a társadalmi egyenlôség kibontakozásában jelöli meg, melynek terén az Egyesült Államok világraszóló eredményeket könyvelhet el politikai, bőrszín szerinti, nemi és fizikai állapotot érintô viszonyok terén, eltekintve az ellenkezô irányba mozgó jövedelmi és vagyoni viszonyoktól. b) Épp az a kulcsproblémája, hogy a társadalmi egyenlôtlenséget a többségi érdekek ellenében miért és miként konzerválja közgondolkodás és az elôrehaladást fékezô ideológia. c) A konfliktusok dinamikájával a stabil demokrácia keretei között számol. d) Úgy véli, az emberek céljait és eszközeit a kilátások észlelt valószinúsége nagyban befolyásolja, az azonban számukra valószínútlen, hogy jogaik gyakorlásában korlátoznák, vagy ezért retorzió érné óket. e) Így az elmélet egy gazdasági húzóerôt képviselő, világháborúkban próbált, szuperhatalmi pozíciót élvezô sikeres társadalom öntudatával és összefogásával szembesül és szembesít (legalább is így volt ez az ezredforduló évtizedeiben).

Az ezredforduló Magyarországán - hogy vegyük a mi régiónk egyik prototipikusnak tekintett társadalmát - ezek a premisszák nem maguktól értetődôek:

a) Ebben a Baltikumtól a Balkánig terjedô puffer régióban viszonylag korán érzékelhetôvé vált, hogy a világháború végének vége közeledik, a rendszerek világrendszere felbomlik. b) Nemcsak az egyenlôség gondolata kompromitálódott az úgymond kommunizmus térhódításával és összeomlásával, hanem magát a fejlôdés perspektíváját kikezdi a múlt. A globális verseny világától való visszahúzódás ezernyi jele közt ott van a településhatárra rovásírással kitett helységnév, a Horvátországot is inkorporáló Nagy-Magyarország emblémák és irodai térképek sokasága, a parlamentbe táncra invitált táltos, a keleti rokonság és szellemi közösség hangsúlyozása, a kereszténység elôtti pogány és a bástyaként keresztényvédô vitéz magyarok kultusza. c) Az önállóságát 1526 után elveszítô ország évszázadokig az államát sem érezhette sajátjának, a feudalizmus hoszszú élete beárnyékolta még parlamentarizmusát is, aminek groteszk végkifejlete volt, hogy a trianoni békével néhány évtizedre visszanyert szuverenitása idején a császárt és királyt szárnysegédjével pótolták. A demokráciának csak elvetélt kezdeményei voltak 18-ban, 45 után, 56 heteiben, érlelố tapasztalata nem. d) A vagyon- és jogbiztonságot itt sokszorosan megtépázta a 20. század, melynek során a soknemzetiségú ország példátlan méretû terület- és vagyonvesztést élt meg, majd maga is rabolta a zsidó vagyont, a világháború idején megingott németséget kisemmizte és javak nélkül menekült magyarokat telepített helyükre, a nagybirtokon és nagytôkén túl egzisztenciálisan felmorzsolta a középosztályt is, a rendszerváltáskor elherdálta és hagyta magánkézbe venni 
az állami tulajdont, munkateljesítményüktôl függetlenül sorsukra hagyta a munkavállalók tömegeit. e) Ilyen körülmények között - melyeket képtelenség pusztán a posztkommunista kategóriával jellemezni - könnyúszerrel elképzelhetô, hogy félresiklik a rendszerváltás szociális, majd piacgazdasági demokrácia programja. Lehámlik „a nép fiainak” egy uralomra törô csoportjáról, amelyet az egymást váltó liberális, demokrata, polgári, nemzeti és keresztény címkék kevésbé jellemeznek, mint a kommunista múlttól, a túlélô riválisoktól és rendszerváltáskor leszakadó néprétegektôl való tudatos elhatárolódás. 2010 korszakos fordulata után a bennfentes nép- és jogismeretre egyaránt építô rendszernek többféle olvasata van. Így az is, hogy legfóbb ambíciója a politikai és gazdasági hatalom kisajátító koncentrációja, mindennemú kontroll kiiktatása, az indulatokra és indulatokkal játszó kommunikáció, az uralkodás vágya a múlt és - a kormányzat nyomait majd megôrzô - jövô felett. A legfájóbb aggály mindemellett az elônytelen helyzetú, kiszolgáltatott és esendô rétegeknek kegyetlenül következetes leszoritása és megfosztása az egyéni és közös megküzdés lehetôségeitôl, nem utolsósorban az oktatás révén végbemenô társadalmi mobilitástól. Ha ebben van igazság, akkor a rendszerigazolás általános tendenciájának itt e társadalmi-kulturális közegben összehasonlíthatatlanul kevesebb a fogódzója, mint az Amerikai Egyesült Államokban, sốt kifejezetten rendszerkritikus érzések és megfontolások jelentkezése várható.

A rendszerigazolás elméletét a haladott világra kiterjedô széleskörú leíró és kísérleti vizsgálatok jellemzik, a rendszerkritikai véleményalkotás után nyomozó saját kutatásainkat inkább úgy jellemezhetjük, mint történeti folyamatkövetố mélyfúrások sorozatát. ${ }^{7}$ Eredményeit ez alkalommal 10+2 tézisben foglalom össze.

1. Nem fér kétség ahhoz, hogy e régióban - hazánkban különösképpen - kevésbé boldog és inkább elégedetlen a közhangulat. A szociálpszichológia kognitív korszaka után, az affektív ellenforradalom idején ez egy sokszorosan vizsgált kérdéskör. A „szubjektív jólét" országos indexét nem egyszer a GDP-hez hasonló jelentôséggel ruházzák fel. A magam részérôl a személyes érzelmi állapothoz képest elkülöníthetônek tartom és relevánsnak ítélem a „társadalmi közérzet” vizsgálatát, amelyben a megélt társas-társadalmi viszonyok, nota bene az emberek észlelt közhangulata jelenik meg - nálunk elkeseredett és elkeserítô tartalommal (Hunyady, 2010a, 2013b).

2. A rendszerigazolás elmélete nagy jelentôséget tulajdonít a biztonság keresésének és érzetének, ami teljes mértékben igazolódott a rendszerváltást követôen hosszú évek során rendszeresen végzett értékvizsgálatainkban.

Több preferált érték - így a rend - társaságában a szociális biztonság elôkelô helyet foglalt el az értékek rangsorában, és ugyanakkor az értékek valóságos érvényesülésérôl érdeklôdve épp vele - és az egyenlôséggel, gazdasági hatékonysággal, demokráciá-

Hazai kutatásainkat John Jost nyomon követte és érdemi kommentárokkal kísérte, miközben ô maga a politikai szociálpszichológia amerikai és nemzetközi életének vezetô alakjává vált. A rendszerváltást követô elsô fázisáról elemzô értékelést nyújtott a Contemporary Psychology-ban (Jost, 2000), megtisztelô méltatást nyújtott és személyes és munkakapcsolatunk történetét vázolta fel 2012-ben (Jost 2012), a régió jellegzetességeinek szentelt írásukban is utalt egyes empirikus megfigyeléseinkre (Cichocka és Jost, 2014). Mindebbôl kitûnik érdeklôdésünk, szemléletünk és tárgyválasztásaink szoros rokonsága, amit a továbbiakban magam sem gyôzök eléggé hangsúlyozni. Vö. különösen Jost, 2003a, valamint Sidanius és Prato, 2005 kötetek elôszavával. Magyar viszonylatban Jost együttmúködô és vitaparnere volt még Berkics Mihály (von Van der Toorn, Berkics és Jost, 2010; van der Toorn, Jost és Berkics, 2014). 
1. tábla. Spontán gondolattársítások (2012-es adatfelvétel 1000 fốs országos reprezentatív mintán, a százalékszámok az adott válaszkategória előfordulási gyakoriságát tükrözik a válaszadók körében)

Magyarország hívószóra születő gondolattársítások

A haza, otthon, lakhely után

44\% bizonytalanság, kilátástalanság, létbiztonság hiánya

$23 \%$ szegénység, nélkülözés

20\% szomorúság, félelem

Az emberek érzései hívó szóra

$47 \%$ pesszimizmus

$20 \%$ félelem a jövőtől, a munkahely elvesztésétöl

$16 \%$ anyagi bizonytalanság

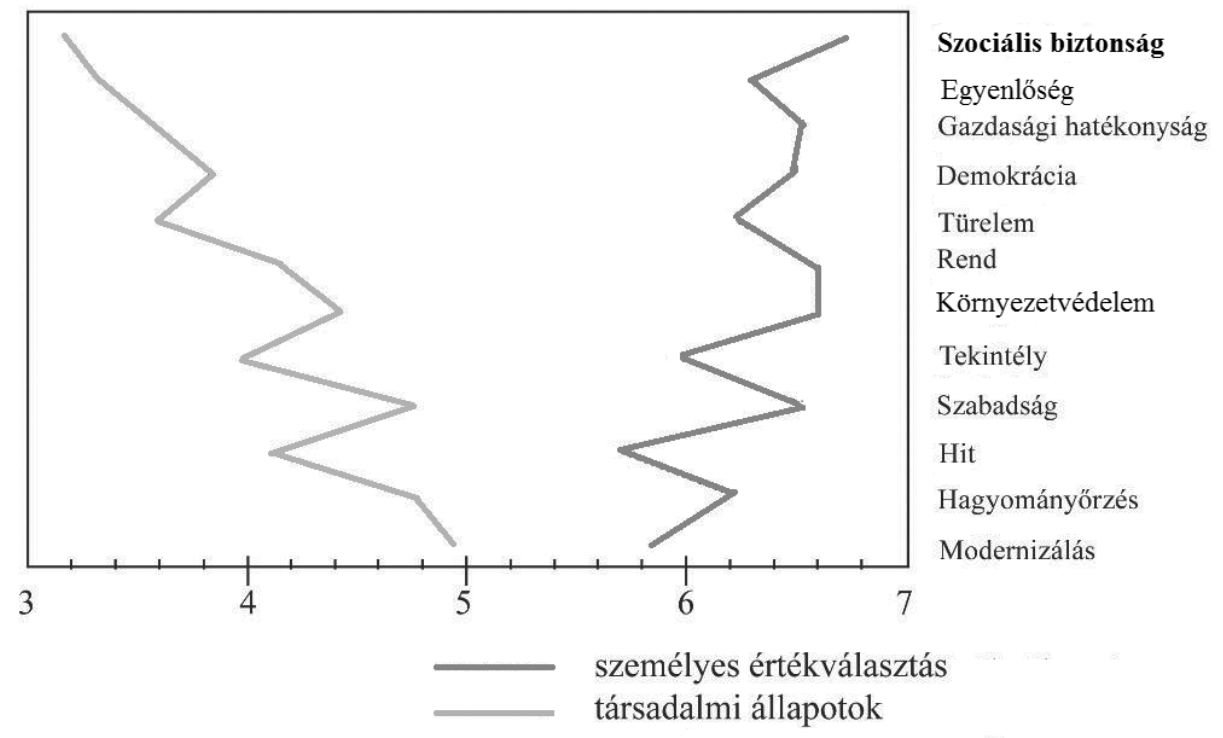

2. ábra. A személyes értékek és a társadalmi állapotok feszültsége, 2012-es értékvizsgálat 1000 fốs országos reprezentatív mintán 
val, toleranciával - kapcsolatban találtuk a legnagyobb feszültséget (mért diszkrepanciát) a kívánalmak és a vélt társadalmi közállapotok között (Hunyady, 2013a). A szociális piacgazdaság ígéretét az egymást forgószínpad-szerúen váltó kormányok nem váltották valóra, a szociális biztonság elvesztésének döntô szerepe volt abban, hogy spirálban futott le a pártok értékelése (Hunyady, 2010c). A rendszerváltás által hozott szabadság, így a (kezdetben szélesebb pártkínálatból való, utóbb a szocialisták és FIDESZ közötti, végül szinte magában a FIDESZ-re esô) választás öröme nem nyújtott kárpótlást az egzisztenciális biztonság elvesztéséért.

3. A rendszerváltás - vagy az aktív jelleget kiemelô rendszerváltoztatás - Jost várakozása szerint az állapotok stabilitásának és a normáknak a megingatásával hangulatrontó (Cichocka és Jost, 2014). Saját sztereotípia-vizsgálataink ezt a diákok homogén mintáinak gondos egybevetése alapján messzemenóen igazolják. Ennek fontos tartalmi mutatója a társadalmi és nemzeti kategóriák csökkent értékelése, nemcsak ideológiaérzékeny kategóriák esetén, hanem minden tekintélyfigura (így a hivatali vezetô vagy az apa) jellemzésében. Illetve kiemelten fontos a saját nemzeti kategória szembeötlő értékcsökkenése, amelyre kihatott az is, hogy e változás révén „a magyar” nemzeti kategóriája a „szovjet blokk” viszonyítási keretéból átkerült az Európa országainak tágabb és igényesebb körébe (Hunyady, 1996b).

A nemzeti és társadalmi kategóriák sztereotip jellemzésének vannak méréssel kimutatható sematikus alkotóelemei: belólük pedig nálunk - úgy tûnik - társadalomkritikus alapállás olvasható ki: minden kategória hibádzik valamiben, ezzel és ennyiben illeszkednek egy összképbe.

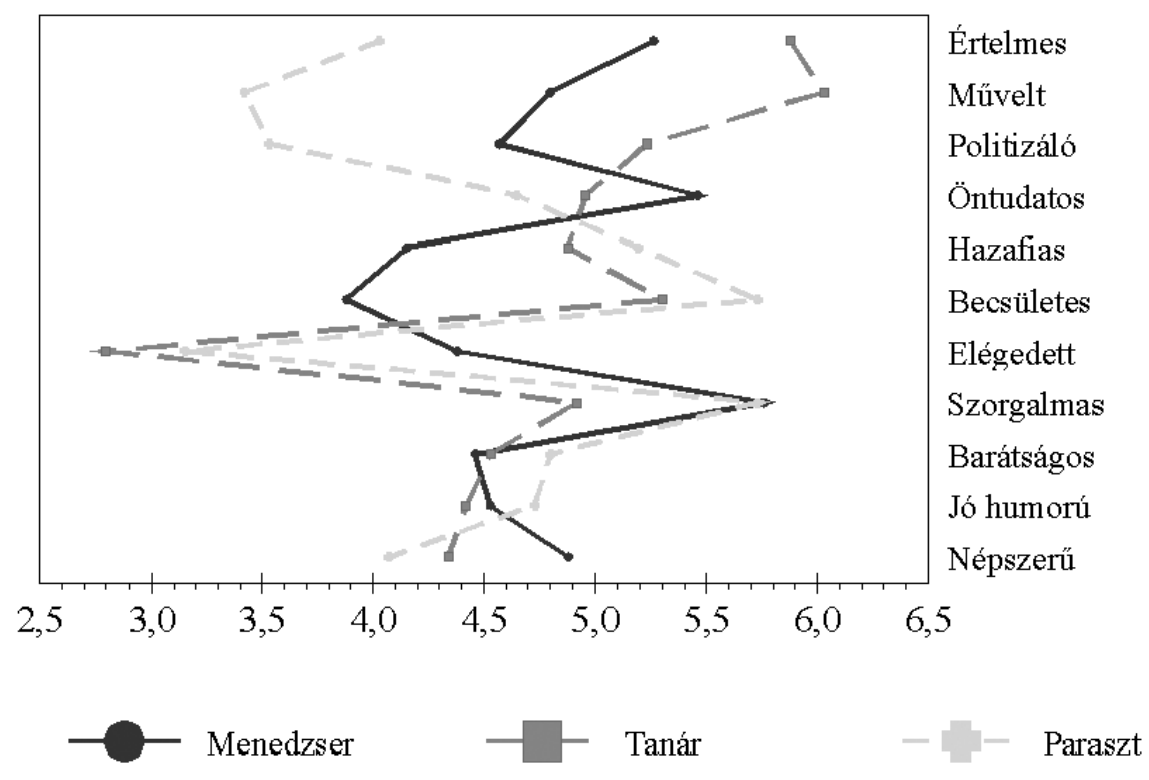

3. ábra. A „menedzser”, a „tanár” és a „paraszt” jellemzésének tulajdonságprofilja 26 fős szelektált középiskolás mintán, 1994 


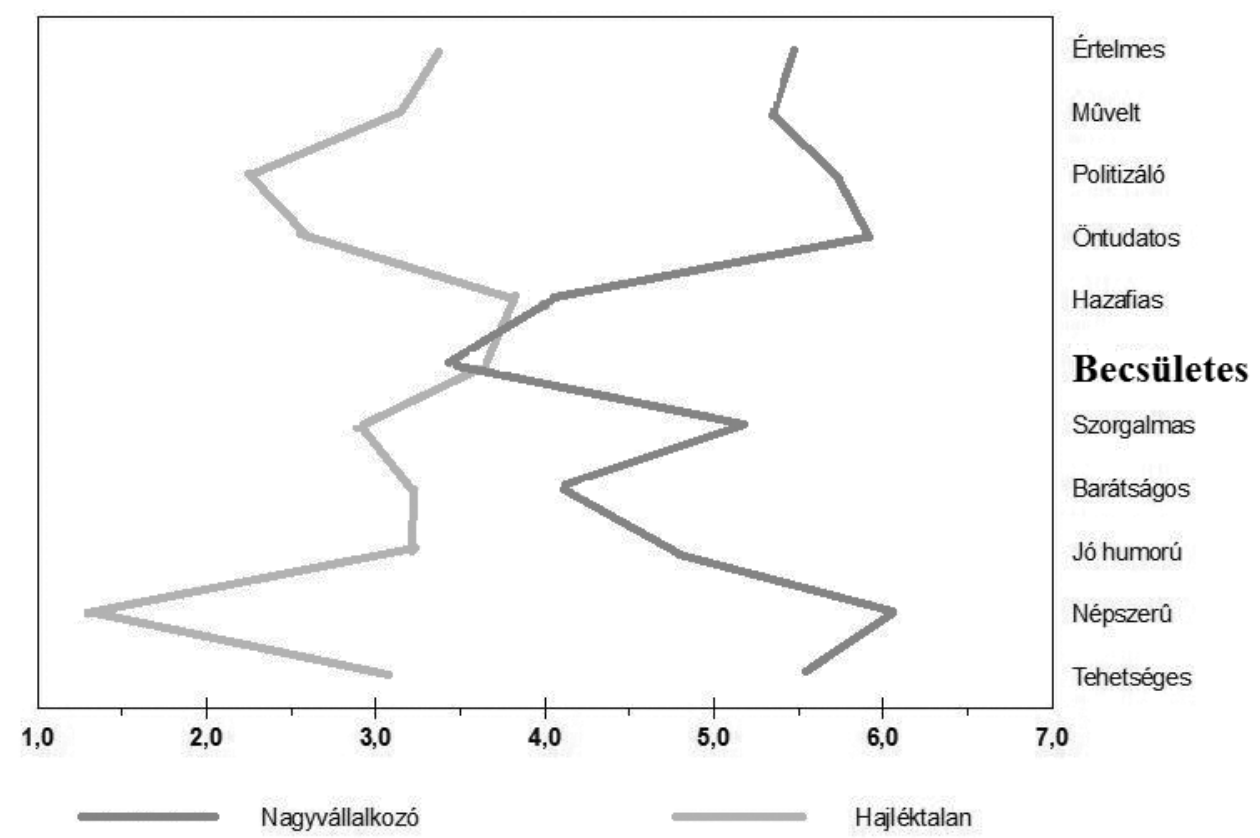

4. ábra. Társadalmi sztereotípiák, 100 fôs differenciált középiskolás mintán, 2001

Vegyük három társadalmi sztereotípia esetét, a középiskolások szenzitív korcsoportja szerint: ezek szerint a paraszt becsületes, de nem múvelt, a tanár múvelt, de nem tetterôs, a menedzser tetterôs, de nem becsületes (Hunyady, 1996b). Ez utóbbinak tulajdonképpen mása az általam többször felidézett, emlékezetes jellemzés a nagyvállalkozóról és a hajléktalanról 2001-bôl: ki ne ismerné el a nagyvállalkozó elônyét minden tekintetben, egyetlen kivétellel: kevésbé becsületes, mint a hajléktalan $(\mathrm{Hu}-$ nyady, 2002). Az egyedi eset általánosítható: a rendszerváltó Magyarországon az új elit, a domináns csoportok képe morális szempontból kérdéses, hibádzik, anyagi és társadalmi kiemelkedésük szélsebessége morálisan hitelteleníti érvényesülésüket.

Ennek a felismerésnek a jegyében számoltam a köznapi társadalomképben egyfelôl az elért siker, státus, másfelôl a tulajdonított emberi, morális értékek szétválásával és szembefordulásával, amikor 2002-ben kidolgoztam és bevezettem egy 50 itemes skálát a rendszerattitűdök vizsgálatára.

A tételek között szerepeltek rendszerigazoló állítások és a rendszerkritika rossz társadalmi közérzetet kifejezô, elmarasztaló ítéletei is. A rendszerigazolás az az álláspont, mely szerint a személyek közötti, illetve a társadalmi kategóriák közötti hierarchikus viszonyok megfelelnek az értékeiknek, emberi kvalitásaik és teljesítményük különbségeinek, tehát a rendszer igazságos. Ennek ellenpontja lenne már az is, ha az értékek és státusok viszonyát pusztán esetlegesnek vagy rendezetlennek nyilvánítanánk. De tovább feszítve a húrt, felkínáltuk azt a végletet is, hogy az értékek, emberi kvalitá- 
2. tábla. Illusztratív itemek a kontraszelekció és rendszerigazolás alskálákhoz

\section{- Kontraszelekció:}

- k46 Az kerül felülre, aki túljár a többiek eszén.

- k38 Ki minél magasabban van, annál inkább visszaél a helyzetével.

- k26 Aki tisztességes, az szegény marad.

- k4 Nem azok élnek jól és azok megelégedettek, akik ezt megérdemelik.

\section{- Rendszerigazolás:}

- r37 Az eredeti gondolkodású, bátor és munkabíró emberek a gazdasági verseny győztesei.

- r28 Aki az utcára kerül, az azért többnyire meg is érdemli.

- r39 Gyönyörködni tudok a gazdag, boldog és szép emberekben.

sok és teljesítmények reciprok módon jelennek meg a státushierarchiában, különösen morális szempontból a magas és alacsony státusúak helycseréje lenne „igazságos”. Ezt neveztük „kontraszelekció-élménynek" és a kontraszelekció lett a rendszerattitúdöt mérô kétpólusú skálarendszer névadója (Hunyady, 2002, 2010d). Eleve ambivalenciával számoltunk és több dimenzióban próbáltuk meghatározni a vizsgálati személyek mentális pozícióját. A nézetrendszer felderítésére számos alkalommal, közöttük 2010 elôtt és után, 4-4 országos reprezentatív mintán került sor (Hunyady, 2015).

A megközelítési szempontokban gazdag itemek fogadtatásában rendre - egészen elenyészô különbségekkel - ugyanaz a válaszstruktúra jelenik meg. Kereshetjük a lineáris összefüggéseket tükröző faktorszerkezetet, az elsôdleges elemzés által felszínre hozott faktorok vizsgálatról vizsgálatra azonosak. Az ezek alapján képzett alskálák belsố kohéziója statisztikai értelemben megnyugtató. (A kutatások összevont 5600 fős mintáján a rendszerkritika alskála Cronbach-alfa értéke 0,84, a rendszerigazolásé 0,70.) Ha a nézetrendszer szerkezetének vizsgálatára adekvátabb klaszteranalízist végzünk, akkor is világosan elrendezôdố itemnyalábokkal fogunk találkozni, amelyek a vizsgálatok sorozatában rendre visszaköszönnek.

Az ábrán az itemek függóleges vonalát keresztvonalak fúzik össze, minél szorosabb a kapcsolatuk, annál alacsonyabban. Két klasztert látunk, mindegyik két szoros tömböt ölel fel. A bal oldali klaszter a rendszerkritika tételeit fogja össze hiánytalanul. A szélsô, kisebbik blokkja a fentlévôket bírálja és a kiválasztódás esetlegességét kárhoztatja, a nagyobb blokkja a kontraszelekció, az igazságtalanság és a maffiauralom vádját fogalmazza meg. A jobb oldali klaszter a rendszerigazolást jeleníti meg, belsô, kisebb blokkja a társadalmi különbségek indokoltságára kedvvel mutat rá, a szélsô, nagyobb blokkja a vezetôk iránti bizalomnak és a jó kilátások optimizmusának ad hangot.

4. A kontraszelekcióra vonatkozó, kiélezetten rendszerkritikus tételek fogadtatása egymással összefügg, míg ezektôl elkülönül a viszonyokat elfogadó, rendszerigazoló állítások köre s ezek fogadtatása. 


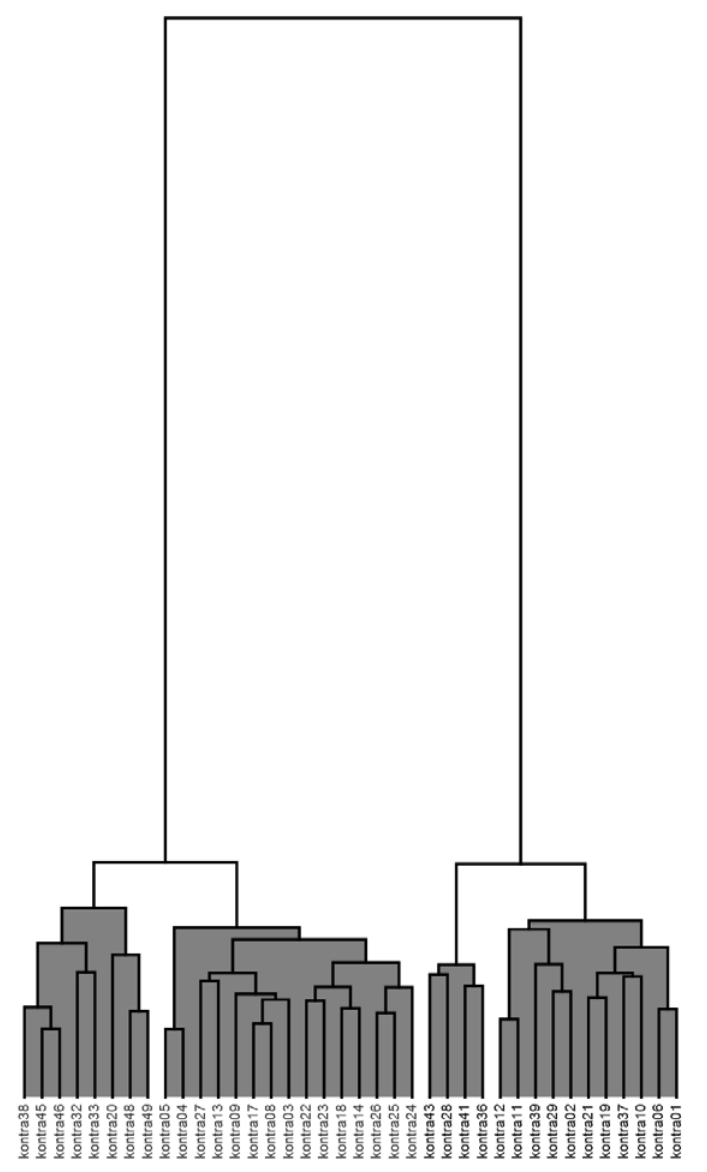

5. ábra. A kontraszelekció-skála itemek klaszterei

5. A hierarchikus viszonyok aktuális igazolása, illetve - alapvetôen morális - kritikája szervesen összefonódik a jövốvel kapcsolatos várakozásokkal.

A rendszerigazolás egyértelmúen és kizárólagosan a pozitív várakozások optimizmusával társul, és tartalmilag mintegy szimmetrikusan a rendszerkritika velejárója a jövô negatív képének pesszimizmusa. E két gondolatkör belsô egysége és egymástól való szétválása a közgondolkodás lényeges tartalmi jellemzôje.

Ha a faktoranalízis alapján alskálákat képezünk, bemutathatjuk az indexeik között mért együttjárások értékeit. A rendszerigazolás és rendszerkritika között gyakorlatilag nincs kapcsolat, az optimizmus és pesszimizmus viszont szignifikáns negatív korrelációban áll. A rendszerigazolás egyértelmú pozitív kapcsolatban áll az optimizmussal és azzal a tételsorral, mely szerint erófeszítésünkön múlik a siker. A rendszerkritika és a pesszimizmus kapcsolata mindenekközül a legerôsebb. A rendszerkritika és az opti- 
3. tábla. Illusztratív itemek a pesszimizmus és optimizmus alskálákhoz

- Pesszimizmus:

- p8 Az ember azt hinné, hogy már nem lehet rosszabb, de mégis egyre tovább süllyed a társadalom.

- p14 A gazdagok gazdagodnak, a szegények csak szegényednek.

- p13 Ez az ország a maffiózók paradicsoma.

\section{- Optimizmus:}

- o11 Bízom a népben, hogy a legjobb vezetőket választja meg.

- o29 Az emberek többsége ma sokkal optimistább, mint volt valaha.

- o2 Soha ilyen elégedett és bizakodó nem voltam, mint manapság.

mizmus negatív kapcsolata még számottevô, egyebekben a két változócsoport között halványak és erôtlenek az összefüggések.

6. A rendszerrel kapcsolatos attitűd ambivalensnek bizonyul, két egymással össze nem simuló komponense többé-kevésbé kötetlenül kombinálódik.

Ez láthatóvá is válik, ha vizsgálatonként, vagy a vizsgált összpopulációt tekintve az összes személyt az itemekre adott válaszaik alapján - elôre megszabott számú - négy klaszterbe soroljuk. A személyek elrendezôdése látványosan megmutatja, hogy a két attitûdkomponens magas és alacsony értékei milyen módon és mértékben kombinálódnak, a nézettípusoknak hol húzódik a tartalmi határa, akár e határok, akár a proto-

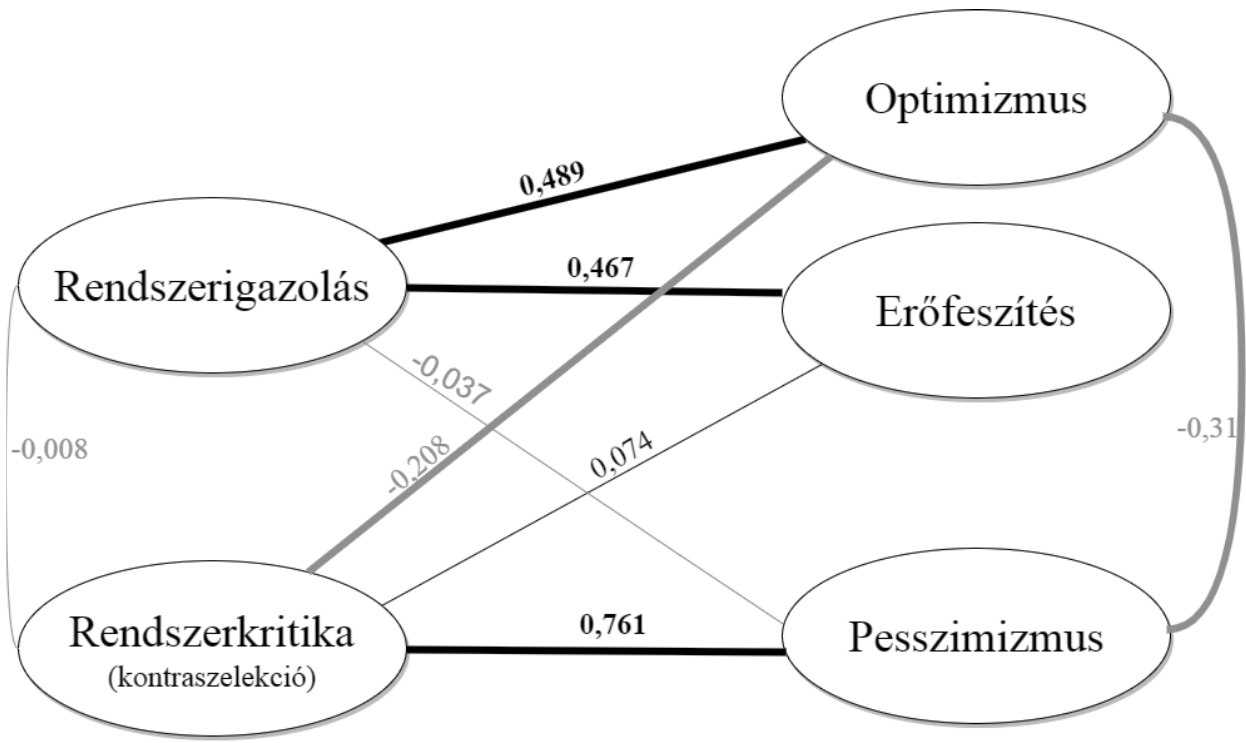

6. ábra. A kontraszelekciós alskálák kapcsolatrendszere 


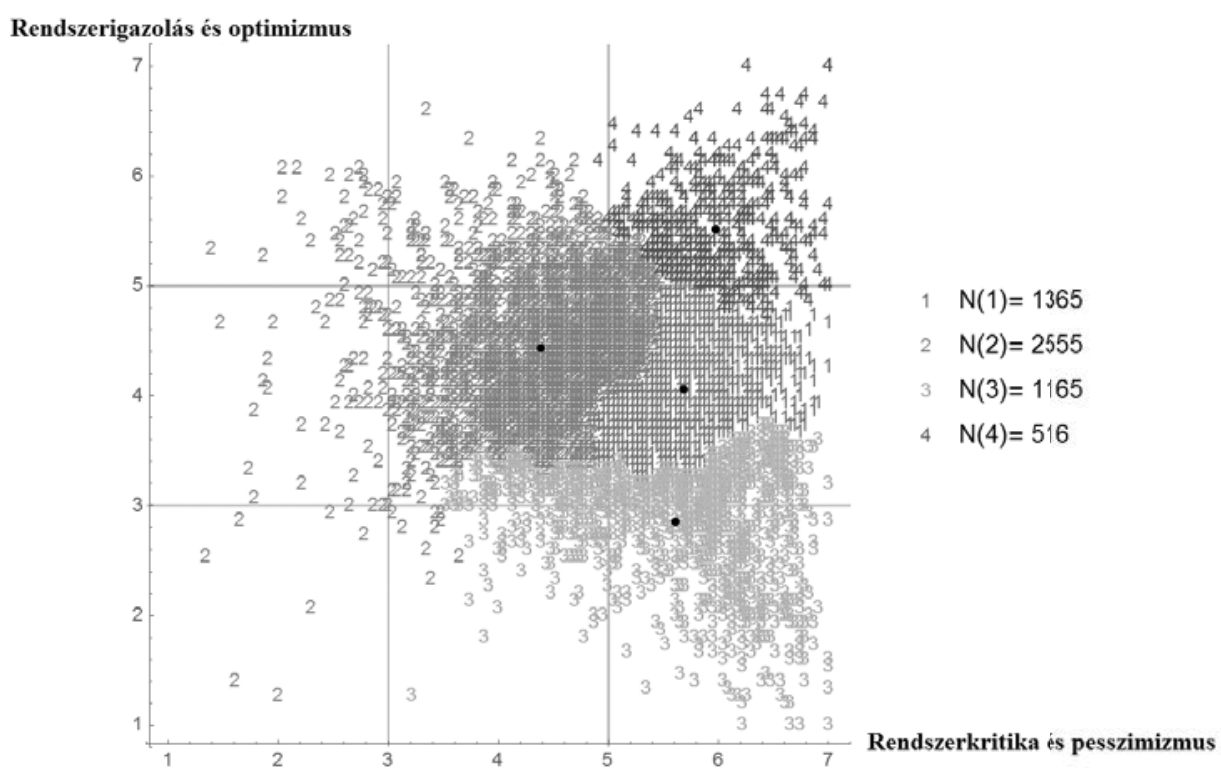

7. ábra. A nyolc vizsgálat teljes populációjának klaszterei

tipikus képviselő helye hogyan módosul, illetve mennyire szilárd az idôben egymásra következó vizsgálatokban.

Mint láthatjuk a különbözô nagyságú csoportok közül egy van, amely rendszerkritika tekintetében - e vízszintes koordinátán - közepes szinten áll, a többi három kifejezetten magas értéket kap. Ez a három csoport a rendszerigazolás függóleges koordinátáján felvesz magas, közepes vagy alacsony értéket. Az igazolás és kritika erôteljes elfogadása logikailag nem kizárt (a tételek elvben megférhetnek egymás mellett), de érzelmi töltete ellentmondásos (hasadt tartalma lehet például a lesújtó összkép mellett jó példák és katartikus változások feltételezése), de bizonyos mértékig alighanem az igent mondás válaszbeállítottságának a terméke. A rendszerigazolás semlegesbe hajló képviselối együttesen szép számmal vannak, egy (2555 fő) részük lényegében ezt a kitérô mentalitást képviseli a rendszerkritika tekintetében is, másik (1365 fô) részük viszont kifejezetten kritikus. A rendszerigazolást elutasító, rendszerkritikát valló konzekvens csoport képvisel egy markáns tartalmi álláspontot.

Ha egy futó pillantást vetünk az országos reprezentatív mintákon végzett 8 kutatás adataira, láthatjuk, hogy az azonos alapon és módszerrel képzett válaszadó csoportokat reprezentáló középérték rendre egymás szomszédságában helyezkedik el, tehát a minták és az idôpontok különbözôsége ellenére jól rokonítható. Az egyetlen mérvadó kivétel - amint erre visszatérünk - a 2012-es év, amikor is a csoportok reprezentációja - jól értelmezhetố módon - elmozdult: technikai nyelven szólva az 1-es csoport rendszerkritikai irányba radikalizálódott, a 2-es és a 3-as csoport közepes, illetve gyenge rendszerigazoló hajlandósága tovább esett. 


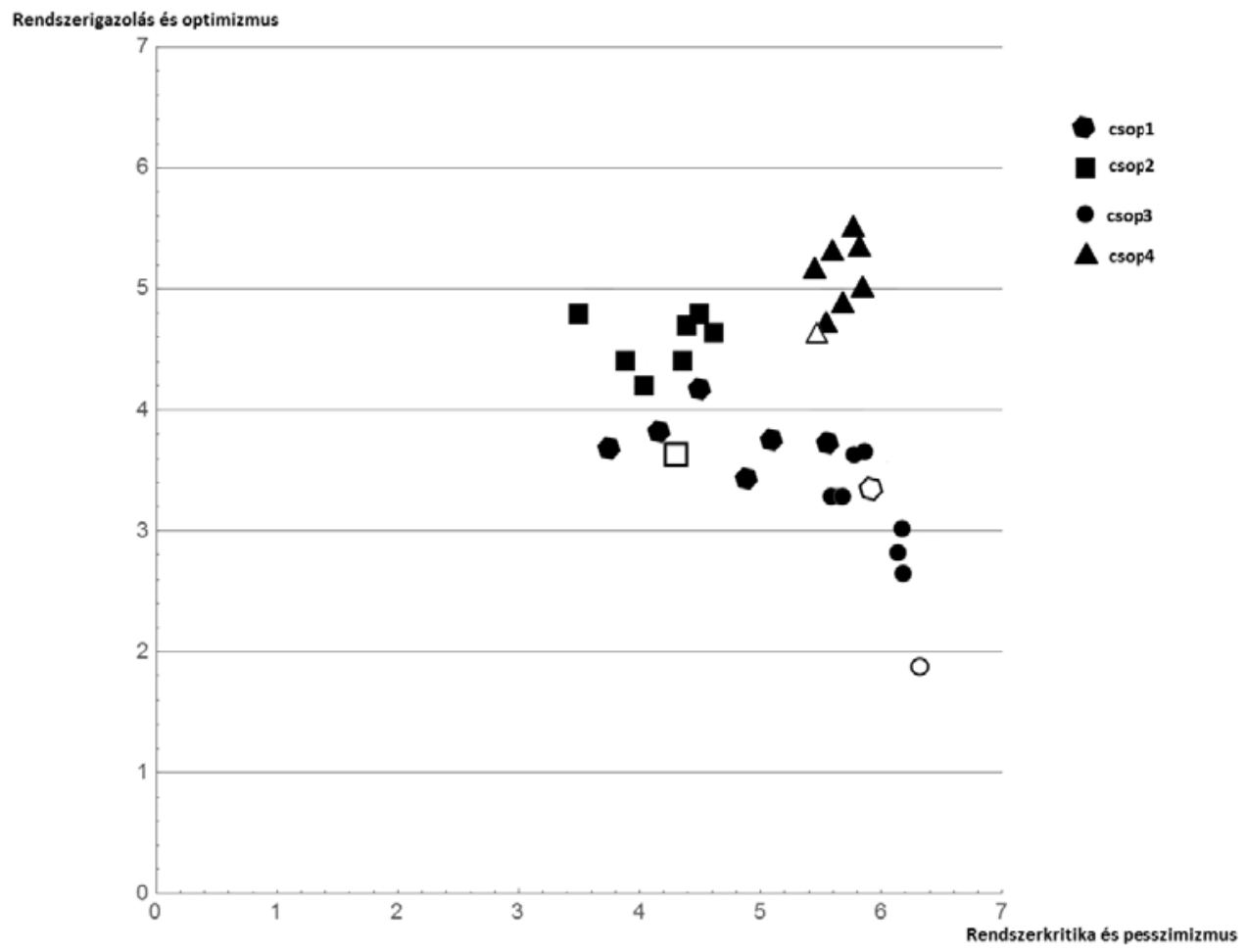

8. ábra. A klaszterek középértékei 4 év vizsgálataiban, az üres ikon a 2012-es év kirívó értékeit jelzi

7. Az országos reprezentatív mintákon szerzett visszatérố tapasztalatok szerint a rendszerkritika-pesszimizmus tételeinek fogadtatása egyértelmúen kedvezóbb, mint a rendszerigazolás-optimizmus álláspontjának elfogadása.

E kettố viszonyában az idốk múltával vannak hullámverések, de töretlenül domináns a negatív megítélés és közérzet: az összevont nagymintán ezen különbség - melynek hátterét az eddigiekben több szempontból analitikusan vizsgáltuk - a 7 fokú skálán rendre megközelíti, sôt meg is haladhatja az 1 teljes fokot. ${ }^{8}$

8. A rendszerattitûd összetettsége is, de domináns minôsége is konszenzuálisnak mondható - amint ezt az eddig kapott összkép sugallja, és amint ezt konstatálhattuk, hiába keresve a társadalmi viszonyokban elfoglalt hely különbségeit. A rendszerigazolás és rendszerkritika tekintetében lehet különbség a politikai kormányzat támogatóinak és ellenzóinek felfogása és közérzete között, de ez az aktuális hatalmi szituációnak megfelelố eltérés csak árnyalatnyi. A rendszerigazolás elméletét mindenekelôtt az támasztaná alá, ha a rendszer alapvetô igenléséhez csatlakoznának a hierarchia alján nyady, 2013a, 2015). 


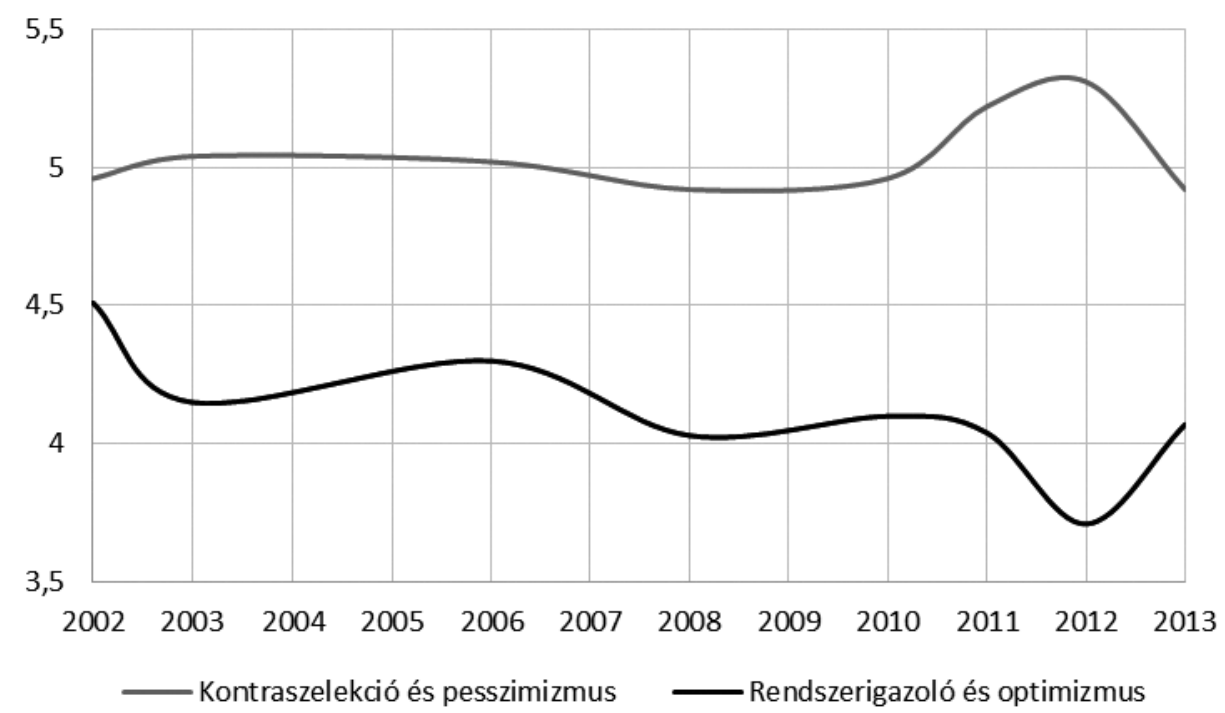

9. ábra. A rendszerattitűd-komponensek alakulása 2002-2013 (Hunyady, 2016)

lévôk is, ehelyett ebben a történeti-kulturális atmoszférában a fenn lévók is alapvetôen a domináns rendszerkritikában osztoznak. (Talán megengedhetjük magunknak azt az egyelőre körvonalazatlan feltételezést is, hogy a rendszerek nemcsak a lent lévôk ostromától vannak - osztályharcos logika szerint - veszélyben, hanem történetileg nem is oly ritkán veszélyeztetheti óket a fent lévôk megosztottsága, vetélkedése, újrarendezési kedve is....)

9. A demokrácia mibenléte, lényege és határai e forgandó idôkben mind többeket foglalkoztatnak 2010 után, amikor a jog szociálpszichológiájának hazai kimunkálásához programszerúen nekiláttunk, a jogelvekre és a joggyakorlatra vonatkozó nézetek körében a közkeletú demokráciafelfogást is vizsgálat tárgyává tettük (Hunyady, 2015, 2016).

Három attitûdöt igyekeztünk megragadni, és ezek típusos együttjárását próbáltuk feltárni. Egyik a demokráciába vetett hit címkét viselte: a kérdezettek el tudják-e képzelni és igénylik-e egységben a többségi uralmat és az egyéni szabadság védelmét ( 7 fokú skálán az összmintaátlaga 5,46). A másik attitûd a kormányzati hatalomösszpontosítás szükségességére és mértékére vonatkozott $(4,45)$, míg a harmadik az állam polgárai közötti különbségtétel tûrését és igényét fejezte ki (3,74). 2010 és 2013 között négy reprezentatív minta válaszai arról tanúskodtak, hogy kifejezett az egyetértés a demokráciába vetett hit tekintetében, a diszkriminációt viszont végsố soron a magyar minták elutasítják.

A három komponenskombinációi közül a leggyakoribb a demokráciába vetett hit kinyilvánítása mellett a hatalomösszpontosítást is elfogadhatónak vallja (36,5\%). Ennél kevesebben vannak, akik a demokrácia mellett egyértelmúen és kiemelten hitet tesznek, és elhárítják a hatalomösszpontosítást (29,8\%). 
4. tábla. Illusztratív itemek a demokráciaattitûdök összefüggéseire

- Demokráciába vetett hit:

- d26 A demokrácia ereje abban rejlik, hogy a kormányzatot lehet bírálni, és ha hibázik, akkor a szabad választáson le is válthatják az emberek.

- d12 A demokrácia azt jelenti, hogy mindenkinek van joga és lehet véleménye, akár a többség akaratával szemben is.

- d9 A demokrácia azt jelenti, hogy a többség akarata érvényesül.

- Hatalomösszpontosítás:

- d24 Az ellenzéknek tudomásul kell venni, hogy a kormány a felelős az országért és nem szabad állandóan megzavarni a munkáját.

- d23 Ha rátermett az ország vezetése, tartsa meg a hatalmat, a választás nem arra való, hogy mindig váltogassuk, kik vezessék az országot.

- d22 Az emberek nagy többsége úgyse látja át az ország ügyeit, ezért aztán nem is lehet az ő véleményükre építeni a felelős politikát.

- Megkülönböztetés:

- d3 Egyes embercsoportok egyszerũen alacsonyabb rendűek, mint mások.

- d17 A kisgyerekeknek, betegeknek és öregeknek nem lehetnek ugyanolyan jogai, mint a felnőtt beszámítható, cselekvő́képes embereknek.

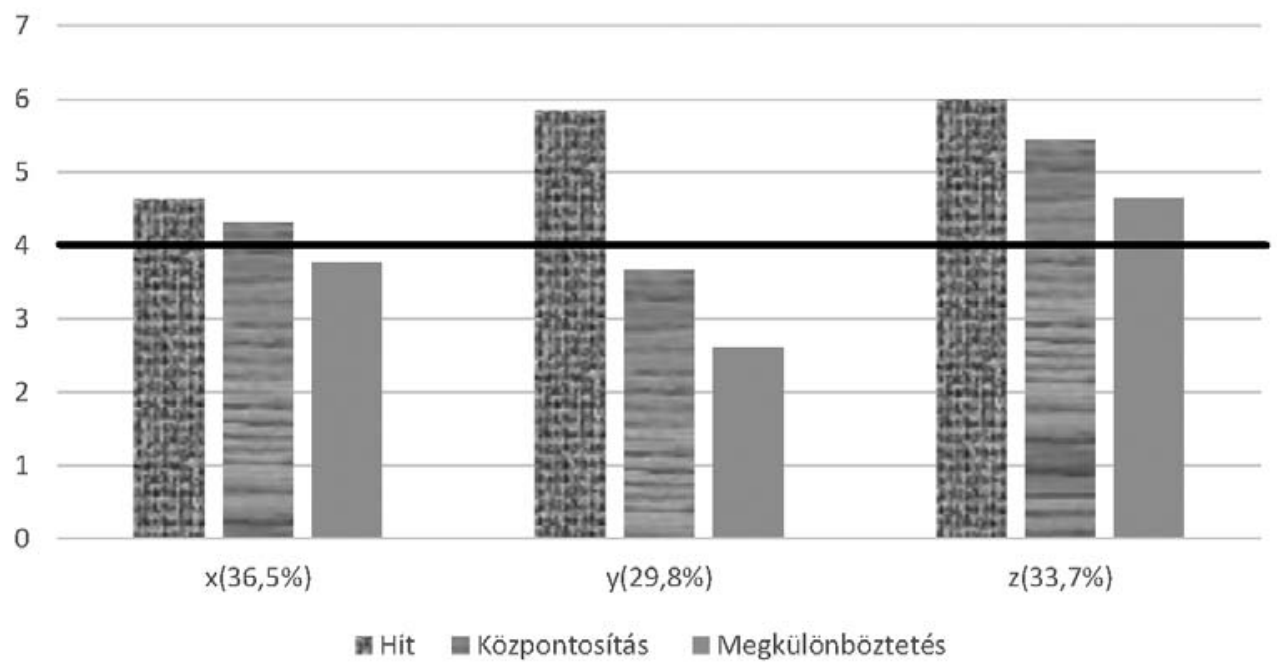

10. ábra. A három nézettípus gyakorisága és attitúdprofilja (Hunyady, 2016)

10. E négy évben ugyanezen mintákon tanulmányoztuk a rendszerigazolás-rendszerkritika alakulását is: a rendszerkritika-pesszimizmus változó a demokráciába vetett hittel, a rendszerigazolás-optimizmus változó viszont mindenekelốt a kormányzati hatalomösszpontositással, ám a társadalmi megkülönböztetéssel is szignifikánsan korrelál.

Az alskálák szintjére bontva a rendszerkritika valamivel erôsebb, a pesszimizmus némileg gyengébb pozitív korrelációban áll a demokráciába vetett hittel, a rendszerigazo- 


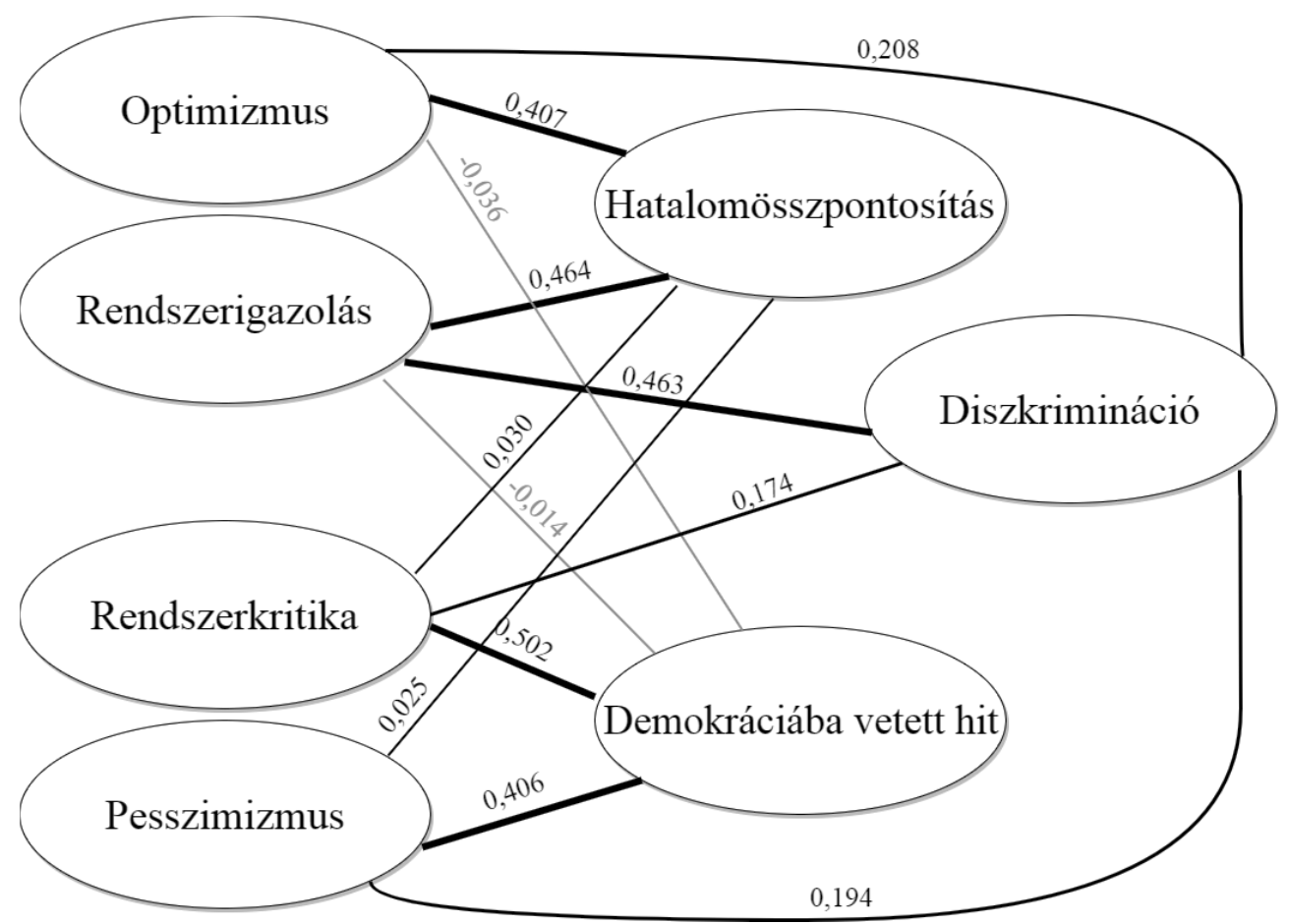

11. ábra. Kontraszelekciós alskálák és a demokráciaattitûdök összefüggései

lás némileg erôsebb, az optimizmus gyengébb kapcsolatban a hatalomösszpontosítás változójával, a zömmel negatív keresztösszefüggések érdemben nem szignifikánsak. E tekintetben különlegesnek és különösnek mondható a diszkrimináció változójának szerteágazó kapcsolatrendszere, de ennek legmarkánsabb eleme kétségtelenül a rendszerigazoláshoz köti. Mindez bizonyos értelemben fényt vet a rendszer és a rendszerattitûdök társadalmi természetére és irányultságára.

Hazai kutatásaink ugyancsak kivonatos áttekintése után, hadd tegyem fel azt a kérdést, hogy e tapasztalatoknak van-e relevanciája a rendszerigazolási elmélet nézópontjából. Az együttgondolkodás szellemében négy pontot emelnék ki:

\section{A kutatás tárgya bipoláris attitüd}

A rendszerigazolás egy pozitív attitúd átélése, érvelô kinyilvánítása és (elvitatásába ütközve) annak felerósítése. Egy attitûd azonban nem korlátozódik sem elvben, sem gyakorlatban a pozitív minôségre és térfélre. Kristályosan tiszta, végletesen leegyszerúsítô definíciója szerint az attitúd az értékelés teljes, pozitív-negatív kontinuumában elfoglalt pozíció. Az egyén vagy csoport társas-társadalmi helyzetének megélését akkor lehet árnyaltan leírni, ha a sokféle forrásból fakadó elégedetlenség jelentkezésével és 
mértékével is számot vetünk. ${ }^{9}$ A pszichológia egész motivációs tana kínál támpontokat ehhez. Elég csak utalni a különbözô szükségletek kielégítésének, a szuverenitás megélésének, a társas-társadalmi összehasonlításoknak a töménytelen problémájára, nem feledkezve meg arról sem, hogy a teljesítmények, jutalmak, relatív pozíciók kiértékelése nem statikus, hanem az igények mozgó mércéje szerint alakul. Tehát két pólus van, és hozzátehetjük, hogy az attitûdtárgy megítélése több szempontból tevôdik össze, ezek egymással birkózva a konzisztens értékelés felé törekednek, de bizonyos kétértékúség, ambivalencia a valóságos attitúdöt mindig is jellemzi.

Mindez független az amerikai és a magyar történeti tapasztalatok és kilátások különbségeitôl, nota bene az elégedettség és elégedetlenség kinyilvánítását szabályozó bevett társadalmi normáktól (hogy ott személyes élethelyzetével nem lehet valaki elégedetlen, itt az elégedettség a visszatetszô). E különbségek csak erôsítik annak tudatát, hogy a rendszerattitûdök bipoláris jellegúek és méltán számíthatunk ambivalenciájukra.

\section{A társadalmi viszonyok rendszere összetett és differenciált attitúdtárgy}

A „rendszer” komplexitása szinte kimeríthetetlen, meghatározása örökkön örökké finomításra szorul. Ennek a különleges attitúdtárgynak részese maga az attitúdöt formáló egyén, ez öleli fel és strukturálja teljes átlátható környezetét, különös tekintettel az embernek embertársaihoz füzôdô hangsúlyos viszonyaira. A rendszerigazolás elmélete hangsúlyozza, hogy bármilyen társadalmi viszonyrendszerben él is az ember, motivált arra, hogy a mindenkori társadalmi hierarchiát és benne saját szerepét igazolja. E tendencia jelentkezését elismerve érdemes nyomába eredni annak a John Josttól is olvasható gondolatnak, hogy a rendszerek különbözó támpontokat nyújtanak az igazolásra (és tegyük hozzá, kritikára) (Cichocka és Jost, 2014). Nem feledkezhetünk meg arról, hogy vannak sikeres és csôdbe futó rendszerek, vannak lendületes és lefojtott atmoszférájúak, vannak átjárhatatlan és rugalmasan alakuló hierarchiák, vannak fenyegetéssel korlátozó és ösztönzéssel kecsegtetô, vannak dogmáikba zárkózó és másokra nyitott társadalmak, végsố soron vannak a társadalmi közérzet szempontjából jobb és rosszabb társadalmi berendezkedések. S ennek a minôségnek valóban egyik perdöntô

9 A rendszerigazolás elmélete is számol ambivalenciával, de alapvetôen nem a rendszerattitűdben, hanem a lent lévôk saját csoportsztereotípiájában (Jost és Burgess, 2003), ami talán az általánosabb inkonzisztenciának csak egy sajátos esete. Egyrészt csak ebben a relációban gondolkodva a rendszer és a csoport (nota bene az egyén) közötti potenciális feszültség meglehet, hogy a rendszer megítélésének ambivalenciájában is megjelenik (vö azzal, hogy a rendszer normatív és tényleíró képe között van különbség és ez bizonyos csoport- és személyi perspektívában ki is élezôdhet). Másrészt a rendszertôl remélt rend ideálképében is mutatkozhatnak törések és több-kevesebb erôvel megjelenhetnek egymással vetélkedô értéktörekvések: ne engedjen ember és ember helyzetében különbséget, vagy legyen hierarchikus, és a benne elfoglalt hely függjön a teljesítménytôl, ám ez utóbbi is többféle nézôpontból mérlegelhetô (mint hatékony munkavégzés, mint társas-társadalmi hatékonyság, esetleg mint emberimorális helytállás) és ezen mérlegelések eredménye erôsen divergálhat. Harmadrészt a rendszer a múltban megélt, vagy a látótérbe került alternatív társadalmi berendezkedésekkel egybevetve, ezek mércéjén mérve többféle, keveredô vagy épp ütközô megvilágításba kerülhet. Negyedrészt a rendszer megítélése természetes módon változik az időben, amint változó feltételek között mutatkozik többé vagy kevésbé hatékonynak, vagy - hogy egy kifejezetten pszichológiai szemponttal is számoljunk - újdonságértékébôl veszít, unalom lepi el megkopó szimbólumait, szereplôit, viszonyait, az élet dinamikájával együtt járó generációváltás hátráltatója lesz vagy legalábbis annak tûnik. Ma ezek szórt ötletek, de egyszerûen ki nem zárható megfontolások. 
kritériuma, hogy milyen vonatkozásban mekkora különbséget diktál, termel ki, tûr meg ember és ember között. Eközben az egyenlôség (akár az esélyek egyenlôsége) az egyének és csoportok gyarapodásának, hatalmának, rangjának erôs motivációjához képest az igazságosság vágyteli álma, amelyhez csak közelíteni lehet különbözô vonatkozásokban és bizonyosan nem ellentmondásmentesen. Ebben a vonatkozásban mégis többet ígérnek és nyújtanak az elvben a közjóra törekvő, tényleges választói kontroll alatt álló demokráciák, még ha a jogállam körmönfont nehézkességével járnak is el, mint az erôre és erôszakra épító, égi és földi illúziókba kapaszkodó autokratikus rendszerek. De ez utóbbiak között is voltak és vannak számottevố különbségek, és húzódik közöttük olyan határ, melyen túl csak romlott cinizmussal lehet állítani, hogy bennük az igazságosság, az egyenlốség, a közös emberi identitás méltányolható módon érvényre jut. (Hisz az egy szakirodalmi tévedés, hogy a rendszerigazolás megkérdôjelezése lenne cinizmus, épp hogy a jogos rendszerkritika naivitással álcázott tudatos semmibevétele az - Schyns, Nuus és Dekker, 2005; Berkics, 2007.)

Úgy vélem, hogy távol vagyunk a rendszersajátosságok és alkalmazkodási módok felderítésétôl és tipizálásától, de ezek keresésének szándéka - ami tanulmányainkban jelen volt - sikerrel kecsegtetô feladat.

\section{A rendszerattitüdök a rendszerváltozások kontextusában nyerik el jelentésüket}

A rendszer lényegéhez tartozik valamiféle állandóság, egy rend, amihez igazodni lehet és kell, ugyanakkor azt nem feledhetjük, hogy ez a konzisztencia a változások világában tûnik fel és abba olvad bele, változásban születik és változásban szúnik. A mai közállapotok megélése és megítélése korántsem független attól, hogy - mit tudunk - mi volt itt a múltban, annak hátterén fejlôdésnek vagy elnyomorodásnak látjuk-e a jelen viszonyokat. Viszonylag tudatlan emberek fejében is valamiféle fejlódésvonal rajzolódik ki, legyen az viszonylag kurta, akár elnagyolt, sztereotipikusan kiüresedett. Különös jelentôsége van annak, hol vonjuk meg a múlt és jelen határát, de e mögött is ott sorjázhatnak az elhatárolt történeti korszakok. A kategóriahatárokon belül asszimilálódnak az értékítéletek, a kategóriahatárok viszont kontrasztosan kiemelik a különbségeket. A múlt rendszer elkötelezett hívei rosszallóan fogadják a bekövetkezett változásokat, de ami szociálpszichológiai szempontból érdekesebb, az az, hogy a jelennel való elégedetlenség aktívan kihat a múlt nosztalgikus felértékelésére (Hunyady, 1996a, 2010b). Ennek van egy olyan kiegészító interpretációja, hogy a múlt problémái az emlékezetben elsikkadnak, a jelen akkor meg nem tapasztalt problémái viszont rányomják bélyegüket az összehasonlításra (Schwarz, Wänke és Bless, 1999; Hunyady, 1996a). Ezt a közérzeti dinamikát látványosan demonstrálták a hazai empirikus vizsgálatok, amikor is a rendszerváltás gondjai, feszültségei, erkölcsi problémái emeltyúként múködtek a Kádár-korszak tömeges értékelésében, amely felszínezte a megterhelt, kifakult, felbomlott múltat, dacolva a politikai és tömegkommunikációs túlnyomással is. Generációs változások is közrejátszhatnak abban, hogy ez a visszahatás mára csökken, viszont a korábban gondokkal megterhelt rendszerváltás 2010 után kezd új, kedvezó fényben megjelenni, mint különösen ígéretes korszak (Hunyady, 2014). A köztudatban élô periódusok különbözô előjelú közkeletű értékelésével - ha nem is szociálpszichológiai tudatossággal - játszik a mindenkori emlékezetpolitika is. Így próbálja ma átszabni a 20. századnak a köztudatban élố emlékezetét, amelynek fejlốdésvonala egy W alakot 
formál ki, melyben a mélypontokat a Horthy- és Rákosi-korszak jelenti. Ezt korrigálná a Horthy-korszak kultuszával és a Rákosi-Kádár-korszakok egybegyalulásával. Ennek újfent makacs akadályai vannak, nem utolsósorban az, hogy sem a Horthy-korszak, sem a jelen megítélése nem oly ragyogó, hogy jó fényt vessenek egymásra, azt már mellôzve is, hogy mennyire hiteltelen az egykor anyagilag és erkölcsileg kisemmizettek leszármazottainak ábrándos visszatekintése a neobarokknak becézett idôszak hívságos és úrhatnám világára.

A rendszer értékelésében - a történeti kontextusa mellett - természetesen ott van és hat a jelen rendszerek társadalmi-politikai viszonyítási kerete, benne a magyar köztudatnak nemcsak a felszínén, de a legmélyebb rétegeiben is éló nyugat-kelet dimenzió, és az ennek mentén elrendezôdô preferenciák. Nyilvánvalóan nem mindegy az a nemzetközi perspektíva, hogy ki hogy látja: a mai magyar rendszermodell kakukktojás az Európai Unió kissé zilált fészkében, vagy a társadalmi-politikai rendszerek földcsuszamlása következtében az elsố fecske, amelyet egy egész madárraj követ: itt tolonganak a környéki papagájok, a történelemból jól ismert dögkeselyúk, és a mára kelekótyává vált büszke sasmadarak is. Az utóbbi önkép talán túlméretezett, bár a szocializmus eszméit kompromitáló szovjet birodalom összeomlása kétségtelenül megrengette a rendszerek világrendszerét. Helyes, ha - anélkül, hogy dramatizálnánk ôket - nem tévesztjük szem elól az egyensúlyok megbomlásának egyes jeleit: Az egyedüli szuperhatalom szerepzavarát, beleértve a demokrácia avatatlan exportjának ballépéseit. A tôkekoncentráció elvadulását világszerte a jóléti állam ideáljának elhalványulásával. A középosztály megrekedését, szétmállását, süllyedését, és ezzel a demokratikus jogállam stabilitásának elvesztését. A piacok és a politikai keretek kitágításának számító racionalizmusával szemben a határokat, normákat, életsztenderdeket vesztô tömegek kiszámíthatatlan indulatait. Mozgalmakat, amelyek emlékeztetnek, de mind gyakrabban szántszándékkal emlékeznek is a világháború elôtti jobboldali radikalizmusra, az emberi méltóság megcsúfolására. Felmérhetetlen erejú új rendszereket, amelyek szervetlenül, de riasztó hatékonysággal egyesítik a politikai diktatúra kijegecesedett és a vadkapitalizmus buzgárszerú társadalmi hierarchiáját. Ám ne higgyük, hogy a rossz eredetból nem fakadhatnak jó fejlemények - tanítja McGuire (2001) is, a közkeletú nézeteket dezorientáló gondolati dinamikáról szólva.

\section{A rendszerattitüdök a változások valószinúségének függvényében alakulnak}

Mondhatjuk egyszerúbben: a status quo értékelése a tekintetben sem magában áll, függ attól, hogy van-e a köztudatban a rendszernek alternatívája, és milyen esélyt látnak megmaradására, illetve lecserélésére. Ezzel az összefüggéssel a rendszerigazolás elmélete maga is kimondottan számol, tudván tudva, hogy a valószinúségek percepciója milyen fontos szerepet játszik a rendszerértékelés alakulásában, a hosszú távú stabilitás, illetve az alternatíva hiánya hogyan erósíti azt (McGuire, 1999, 2001; Kay, Jimenez és Jost, 2003; Kay, Shepherd, Blatz, Chua és Galinsky, 2010; Laurin, Gaucher és Kay, 2013; Blanchar és Eidelman, 2013). Talán egy ponton lehetne ennek az összefüggésnek még nagyobb jelentôséget tulajdonítani, ez pedig az elméletépítésben oly fontos felismerés, hogy a társadalom alacsony státusú rétegei inkább választják a hierarchia aktív támogatását, mint a konfrontatív szembehelyezkedést. Ennek hármas motivációjáról is érdemben szó esik, de hiányzik az alávetettek helyzetértékelésének - az 

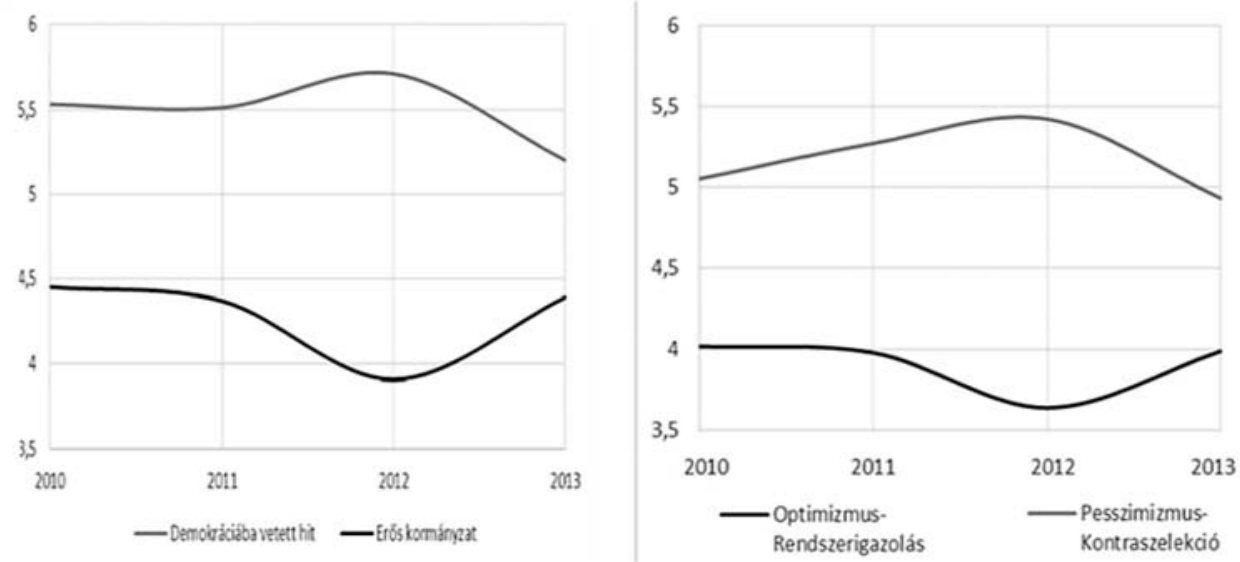

12. ábra. Párhuzamos attitúdhullámok 2010-2013 között (Hunyady, 2016)

autokratikus berendezkedésekben oly evidens - eleme, hogy a hierarchia lebontása a túlhatalom kemény ellenállásába ütközik, már megkísérlése is vészterhes, eredménye több mint kétséges, valószínútlen gyôzelme esetén rendszer-alternatívája gyakran kimunkálatlan és kipróbálatlan. A mi hazai kutatásainkban a részben már mutatott eredmények történeti léptékú példát kínálnak a valószínúség-percepció feltehetô szerepére a rendszerkritika felerôsödésében és a rendszerigazolás regenerálódásában: ez pedig a mostanság oly gyakran felemlegetett 2014 előzményeként 2012 felbuzdulása, majd elhalványulása (Hunyady, 2013a).

Az attitûdmérések esztétikai szempontból is látványos eredménye egyfelól a hasadt rendszerattitûd egymástól függetlenül mért két komponensének egymást kiegészítô együttmozgása, másfelôl a rendszer elvi alapjait érintô demokráciafelfogás két attitûdjének ugyancsak egymást kiegészítô együttmozgása, párhuzamosan. És itt most nem statisztikai értelemben vett (interindividuális jellegú) korrelációkról van szó egy-egy idôpillanatban, hanem nagy minták szövevényes nézetrendszereinek tartalmilag harmonizáló alakulásáról, annak alapján, hogy 2012-re feltûnt egy politikai alternatíva, amelynek nem az összefogása, hanem összefogásának álságossága és nyilvánvaló kormányképtelensége fosztotta meg az alapvetôen rendszerkritikus választói tömeget reményétôl és tetterejétôl. Megjegyzendô, hogy e történeti változások hitelesítették a rendszerigazolás és a hatalomkoncentráció igényének jellemzô kapcsolatát, s vele szemben a rendszerkritika és a demokráciába vetett hit összetartozását Magyarországon. Nota bene az eredmények azt is demonstrálták, hogy a demokrácia szövevényes logikáját hittel képviselôk a rendszer bírálatára hajlanak, de pesszimisták a jövôt illetốen, és hogy e paradoxon szellemében fogalmazzunk, pesszimizmusukban nem is kellett csalódniuk...

E pesszimizmus tehát önbeteljesító jóslatnak bizonyult és bizonyulhat a jövôben is. Hazánk szülötte, George Katona, a pszichológiai közgazdaságtan amerikai úttörôjeként megtanította a legkeményebb társadalomtudomány múvelôiit arra, hogy a 
derülátó köz-attitûd kiránthatja a gazdaságot válságos objektív feltételek közül és ellenében is (Katona, 1960; Hunyady, 2003b). Az lenne egy érdekes társadalmi kísérlet, ha ezt demonstrálni lehetne a politika flexibilisebb közegében is: amihez azonban „depresszív realizmus” (Cichocka és Jost, 2014) helyett derülátó köz-attitúdöt kellene idevarázsolni.

\section{IRODALOM}

Allison, S. C., Mackie, D. M., \& Messick, D. M. (1999). Eredménytorzítások a szociális percepcióban: a diszpozicionális következtetések implikációi, attitûdváltozás, sztereotipizálás és társas viselkedés. In: Hunyady György, D. L. Hamilton, \& Nguyen Luu Lan Anh (szerk.), A csoportok percepciója (130-165). Budapest: Akadémiai Kiadó.

Berkics, M. (2007). Cold hearted cynics vs concerned citizens: re-visiting the notion of social-political cynicism and its Relationship to Citizenship. In A. Ross (Ed.), Citizenship Education in Society (645-656). London.

Blanchar, J. C., \& S. Eidelman (2013). Perceived system longevity increases system justification and the legitimacy of inequality. European Journal of Social Psychology, 43(4) 238-245.

Blasi, G., \& Jost, J. T. (2006). System justification theory and research: Implications for law, legal advocacy, and social justice. California Law Review, 94(4) 1119-1168.

Bonanno, G. A., \& Jost, J. T. (2006). Conservative shift among high-exposure survivors of the September $11^{\text {th }}$ terrorist attacks. Basic and Applied Social Psychology, 28(4) 311-323.

Brandt, M. J. (2013). Do the disadvantaged legitimize the social system? A large-scale test of the status-legitimacy hypothesis. Journal of Personality and Social Psychology, 104(5) 765-785.

Callan, M. J., Kay, A. C., \& Dawtry, R. J. (2014). Making Sense of Misfortune: Deservingness, Self-Esteem, and Patterns of Self-Defeat. Journal of Personality and Social Psychology, 107(1) $142-162$.

Carney, D. R., Jost, J. T., Gosling, S. D., \& Potter, J. (2008). The secret lives of liberals and conservatives: Personality profiles, interaction styles, and the things they leave behind. Political Psychology, 29(6) 807-840.

Cichocka, A., Górska, P., Jost, J. T., Sutton, R., \& Bilewicz, M. (2017). What inverted U can do for your country: A curvilinear relationship between confidence in the social system and political engagement. Journal of Personality and Social Psychology, Advance online publication.

Cichocka, A., \& Jost, J. T. (2014). Stripped of illusions? Exploring system justification processes in capitalist and post-Communist societies. International Journal of Psychology, 49(1) 6-29.

Costa-Lopes, R., Dovidio, J. F., Pereira, C. R., \& Jost, J. T. (2013). Social psychological perspectives on the legitimation of social inequality: Past, present and future. European Journal of Social Psychology, 43(4) 229-237.

Csepeli Gy., szerk. (1980). Elôitéletek és csoportközi viszonyok: Válogatott tanulmányok. Budapest: Közgazdasági és Jogi Könyvkiadó.

Gaucher, D., \& Jost, J. T. (2011). Difficulties awakening the sense of injustice and overcoming oppression: On the soporific effects of system justification. In P. T. Coleman (Ed.), Conflict, interdependence, and justice: The intellectual legacy of Morton Deutsch (227-246). New York: Springer.

Haidt, J. (2001). The emotional dog and its rational tail: a social intuitionist approach to moral judgment. Psychological Review, 108(4) 814-834.

Hennes, E. P., Nam, H. H., Stern, C., \& Jost, J. T. (2012). Not all ideologies are created equal: Epistemic, existential, and relational needs predict system-justifying attitudes. Social Cognition, 30(6) 669-688. 
Hunyady Gy. (1996a). Sztereotípiák a változó közgondolkodásban (268-290). Budapest: Akadémiai Kiadó.

Hunyady Gy. (1996b). A nemzeti kategóriák kognitív területe II.: Nemzeti sztereotípiák. In Hunyady György. Sztereotípiák a változó közgondolkodásban. (107-176). Budapest: Akadémiai Kiadó.

Hunyady Gy. (2000). A tehetség kibontakozásának társadalmi rugói és kerékkötôii. Alkalmazott Pszichológia, 2(4) 5-15.

Hunyady Gy. (2002). A kontraszelekció pszichológiája. Magyar Pszichológiai Szemle, 55(3) 397-434.

Hunyady Gy. (2003a). Társadalomkritikus szociálpszichológia: John Jost tanulmányai. In: J. T. Jost. Önalávetés a társadalomban: a rendszerigazolás pszichológiája (9-26). Budapest: Osiris Kiadó.

Hunyady Gy. (2003b). A gazdaságpszichológia útkeresése. In: Hunyady György, Székely Mózes (szerk.). Gazdaságpszichológia (796-834). Budapest: Osiris Kiadó.

Hunyady Gy. (2005). A társadalmi csoportok értékelố megkülönböztetése: váltott kutatási perspektívák. In J. Sidanius \& F. Pratto. A társadalmi dominancia - A társadalmi hierarchia és elnyomás csoportközi elmélete (7-40). Budapest: Osiris Kiadó.

Hunyady Gy. (2010a). A társadalmi közérzet hullámverése. Budapest: Napvilág Kiadó.

Hunyady Gy. (2010b). A történeti összehasonlítások érzelmi dinamikája. In Hunyady György. A társadalmi közérzet hullámverése (161-190). Budapest: Napvilág Kiadó.

Hunyady Gy. (2010c). Értékvesztés a politikában. In Hunyady György. A társadalmi közérzet hullámverése. (191-231). Napvilág Kiadó. Budapest.

Hunyady Gy. (2010d). A kontraszelekció élményvilága. In Hunyady György: A társadalmi közérzet hullámverése (45-90). Budapest: Napvilág Kiadó.

Hunyady Gy. (2013a). Az elégedetlenség dominanciája. Magyar Pszichológiai Szemle, 68(4) 621-645.

Hunyady Gy. (2013b). A személyes szuverenitás és kiszolgáltatottság élménye. Magyar Tudomány, 174(4) 438-452.

Hunyady Gy. (2014). Visszatekintés a jelenből. In Hunyady György, Török László (szerk.), Történelem és emlékezet: Egy akadémiai ülésszak elôadása (9-26). Budapest: Kossuth Kiadó.

Hunyady Gy. (2015). A demokrácia-követelmények a köztudatban és a társadalmi atmoszféra ambivalenciája. In Hunyady György, \& Berkics Mihály, (szerk.): A jog szociálpszichológiája: a hiányzó láncszem (281-337). Budapest: ELTE Eötvös Kiadó.

Hunyady Gy. (2016). Demokrácia a közgondolkodásban és a társadalmi közérzet. In Hunyady György: Jelentörténeti szociálpszichológia (71-94). Budapest: ELTE Eötvös Kiadó.

Jost, J. T. (2000). Stereotyping as ideology and the psychological transition from communism to capitalism. [Book review of Stereotypes during the decline and fall of communism by G. Hunyady.] Contemporary Psychology, 45, 597-599.

Jost, J. T. (2001). Outgroup favoritism and the theory of system justification: An experimental paradigm for investigating the effects of socio-economic success on stereotype content. In G. Moskowitz (Ed.), Cognitive social psychology: The Princeton symposium on the legacy and future of social cognition (89-102). Mahwah, NJ: Erlbaum.

Jost, J. T. (2003a). Önalávetés a társadalomban: a rendszerigazolás pszichológiája. Budapest: Osiris Kiadó.

Jost, J. T. (2003b) . A külsố csoport előnyben részesítése és a rendszerigazolás elmélete: kísérleti paradigma a szocioökonómiai sikeresség sztereotípiatartalomra gyakorolt hatásának vizsgálatára. In: J. T. Jost. Önalávetés a társadalomban: a rendszerigazolás pszichológiája (109-136). Budapest: Osiris Kiadó. 
Jost, J. T. (2003c). A rendszerigazolás elmélete, mint a társas azonosulás és a szociális dominancia elméleteinek elismerése, kiegészítése és helyesbítése. In J. T. Jost. Önalávetés a társadalomban: a rendszerigazolás pszichológiája (417-460). Budapest: Osiris Kiadó.

Jost, J. T. (2006). The end of the end of ideology. American Psychologist, 61(6) 651-670.

Jost, J. T. (2012). Ideológiák, társadalmi rendszerek és csoportokra vonatkozó értékelések szerkezeti dinamikája. In Fülöp Márta, \& Szabó Éva (szerk.), A pszichológia mint társadalomtudomány: A 70 éves Hunyady György tiszteletére. (89-107). Budapest: ELTE Eötvös Kiadó.

Jost, J. T. (2017a). Ideological asymmetries and the essence of political psychology. (Presidential Adress) Political Psychology, 38(2) 167-208.

Jost, J. T. (2017b). Working class conservatism: a system justification perspective. Current Opinion in Psychology, 18, 73-78.

Jost, J. T., \& Banaji, M. R. (1999). A sztereotipizálás szerepe a rendszer igazolásában, a hamis tudat. In Hunyady György, D. L. Hamilton, \& Nguyen Luu Lan Anh (szerk.), A csoportok percepciója (489-518). Budapest: Akadémiai Kiadó.

Jost, J. T., Banaji, M. R., \& Nosek, B. A. (2004). A decade of system justification theory: Accumulated evidence of conscious and unconscious bolstering of the status quo. Political Psychology, 25(6) 881-919. különösen 893-896.

Jost, J. T., Blount, S., Pfeffer, J., \& Hunyady, Gy. (2003). Fair market ideology: Its cognitive-motivational underpinnings. Research in Organizational Behavior, 25 53-91.

Jost, J. T., \& Burgess, D. (2003). Az attitűdök ambivalenciája, valamint a rendszerigazolás és a csoportigazolás konfliktusa az alacsony státusú csoportokban. In J. T. Jost. Önalávetés a társadalomban: a rendszerigazolás pszichológiája (137-164). Budapest: Osiris Kiadó.

Jost, J. T., Burgess, D., \& Mosso, C. (2003). A self, a csoport és a rendszer legitimálásának ellentmondásai: az elméleti integráció lehetôsége a rendszer-igazolási elmélet segítségével. In J. T. Jost. Önalávetés a társadalomban: a rendszerigazolás pszichológiája (80-106). Budapest: Osiris Kiadó.

Jost, J. T., Chaikalis-Petritsis, V., Abrams, D., Sidanius, J., van der Toorn, J., \& Bratt, C. (2012). Why men (and women) do and don't rebel: Effects of system justification on willingness to protest. Personality and Social Psychology Bulletin, 38(2) 197-208.

Jost, J. T., Federico, C. M., \& Napier, J. L. (2009). Political ideology: Its structure, functions, and elective affinities. Annual Review of Psychology, 60307-337.

Jost, J. T., Federico, C. M., \& Napier, J. L. (2013). Political ideologies and their social psychological functions. In M. Freeden (Ed.), Oxford handbook of political ideologies (232-250). New York: Oxford University Press.

Jost, J. T., Gaucher, D., \& Stern, C. (2014). “The world isn't fair”: A system justification perspective on social stratification and inequality. In J. F. Dovidio, J. A. Simpson (Eds), APA handbook of personality and social psychology. Vol. 2 (317-340). Washington, DC: APA.

Jost, J. T., Glaser, J., Kruglanski, A. W., \& Sulloway, F. (2003). A politikai konzervatizmus mint motivált társas megismerés. In J. T. Jost. Önalávetés a társadalomban: a rendszerigazolás pszichológiája (525-600). Budapest: Osiris Kiadó.

Jost, J. T., Guermandi, G., Mosso, C., Kivetz Y., Pelham, B. W, \& Burgess, D. (2001). A rendszerigazolás elméletének összefoglalása. In Hunyady György, Nguyen Luu Lan Anh (szerk.), Sztereotípiakutatás - hagyományok és irányok (377-388). Budapest: ELTE Eötvös Kiadó.

Jost, J. T., Hawkins, C. B., Nosek, B. A., Hennes, E. P., Stern, C., Gosling, S. D., \& Graham, J. (2014). Belief in a just god (and a just society): A system justification perspective on religious ideology. Journal of Theoretical and Philosophical Psychology, 34(1) 56-81.

Jost, J. T., \& Hunyady, O. (2002). The psychology of system justification and the palliative function of ideology. European Review of Social Psychology, 13, 111-153. 
Jost, J. T., \& Hunyady, O. (2005). Antecedents and consequences of system-justifying ideologies. Current Directions in Psychological Science, 14(5) 260-265.

Jost, J. T., \& Kay, A. C. (2005). Exposure to benevolent sexism and complementary gender stereotypes: Consequences for specific and diffuse forms of system justification. Journal of Personality and Social Psychology, 88(3) 498-509.

Jost, J. T., \& Kay, A. C. (2012). System justification as an obstacle to the attainment of social justice. In J. P. Forgas, K. Fiedler, \& C. Sedikides (Eds), Social thinking and interpersonal behavior (277-296). New York: Taylor \& Francis/Psychology Press.

Jost, J. T., Kay, A. C., \& Thorisdottir, H. (2009) (Eds). Social and psychological bases of ideology and system justification. New York: Oxford University Press.

Jost, J. T., Kivetz, Y., Rubini, M., Guermandi, G., \& Mosso, C. (2005). System-justifying functions of complementary regional and ethnic stereotypes: Cross-national evidence. Social Justice Research, 18(3) 305-333.

Jost, J. T., Kruglanski, A. W., \& Simon, L. (1999). Effects of epistemic motivation on conservatism, intolerance, and other system justifying attitudes. In L. Thompson, D. M. Messick, and J. M. Levine (Eds), Shared cognition in organizations: The management of knowledge (91-116). Mahwah, NJ: Erlbaum.

Jost, J. T., Ledgerwood, A., \& Hardin, C. D. (2008). Shared reality, system justification, and the relational basis of ideological beliefs. Social and Personality Psychology Compass, 2(1) 171-186.

Jost, J. T., Liviatan, I., van der Toorn, J., Ledgerwood, A., Mandisodza, A., \& Nosek, B. A. (2010). System justification: How do we know it's motivated? In R. C. Bobocel, A. C. Kay, M. Zanna, \& J. Olson (Eds), The psychology of justice and legitimacy: The Ontario symposium. Vol. 11. (173-203). Hillsdale, NJ: Erlbaum.

Jost, J. T., \& Major, B. (2001a) (Eds). The psychology of legitimacy: Emerging perspectives on ideology, justice, and intergroup relations. New York: Cambridge University Press.

Jost, J. T., \& Major, B. (2001b). Emerging perspectives on the psychology of legitimacy. In J.T. Jost and B. Major (Eds), The psychology of legitimacy: Emerging perspectives on ideology, justice, and intergroup relations (3-30). New York: Cambridge University Press.

Jost, J. T., \& Napier, J. L. (2012). The uncertainty-threat model of political conservatism. In M. Hogg, \& D. Blaylock (Eds), Extremimism and the psychology of uncertainty (90-111). Boston: Wiley-Blackwell.

Jost, J. T., Napier, J. L., Thorisdottir, H., Gosling, S. D., Palfai, T. P., \& Ostafin, B. (2007). Are needs to manage uncertainty and threat associated with political conservatism or ideological extremity? Personality and Social Psychology Bulletin, 33(7) 989-1007.

Jost, J. T., Nosek, B. A., \& Gosling, S. D. (2008). Ideology: Its resurgence in social, personality, and political psychology. Perspectives on Psychological Science, 3(2) 126-136.

Jost, J. T., Pelham, B. W., \& Carvallo, M. (2002). Non-conscious forms of system justification: Implicit and behavioral preferences for higher status groups. Journal of Experimental Social Psychology, 38(6) 586-602.

Jost, J. T., Pelham, B. W., Sheldon, O., \& Sullivan, B. N. (2003). Social inequality and the reduction of ideological dissonance on behalf of the system: Evidence of enhanced system justification among the disadvantaged. European Journal of Social Psychology, 33(1) 13-36.

Jost, J. T., Pietrzak, J., Liviatan, I., Mandisodza, A. N., \& Napier, J. L. (2007). System justification as conscious and nonconscious goal pursuit. In J. Y. Shah, \& W. L. Gardner (Eds), Handbook of motivation science (591-605). New York: Guilford.

Jost, J. T., Rudman, L. A., Blair, I. V., Carney, D., Dasgupta, N., Glaser, J., \& Hardin, C. D. (2009a). The existence of implicit bias is beyond reasonable doubt: A refutation of ideological and methodological objections and executive summary of ten studies that no manager should ignore. Research in Organizational Behavior, 29(3), 39-69. 
Jost, J. T., Rudman, L. A., Blair, I. V., Carney, D., Dasgupta, N., Glaser, J., \& Hardin, C. D. (2009b). An invitation to Tetlock and Mitchell to conduct empirical research on implicit bias with friends, "adversaries," or whomever they please. Research in Organizational Behavior, 29(3) 73-75.

Jost, J. T., \& van der Toorn, J. (2012). System justification theory. In P. A. M. van Lange, A. W. Kruglanski, \& E. T. Higgins (Eds), Handbook of theories of social psychology. Vol. 2. (313-343). London: Sage.

Jost, J. T., Wakslak, C., \& Tyler, T. R. (2008). System justification theory and the alleviation of emotional distress: Palliative effects of ideology in an arbitrary social hierarchy and in society. In K. Hegtvedt, J. Clay-Warner (Eds), Justice: Advances in group processes. Vol. 25. (181-211). Bingley, UK: JAI/Emerald.

Katona, G. (1960). The powerful consumer: Psychological studies of the American economy. New York: McGraw-Hill.

Kay, A. C., \& Jost, J. T. (2003). Complementary justice: Effects of "poor but happy" and "poor but honest" stereotype exemplars on system justification and implicit activation of the justice motive. Journal of Personality and Social Psychology, 85(5) 823-837.

Kay, A. C., Jost, J. T., Mandisodza, A. N., Sherman, S. J., Petrocelli, J. V., \& Johnson, A. L. (2007). Panglossian ideology in the service of system justification: How complementary stereotypes help us to rationalize inequality. In M. Zanna (Ed.), Advances in Experimental Social Psychology. Vol. 39. (305-358). San Diego, CA: Academic Press/Elsevier.

Kay, A. C., Czaplinski, S., \& Jost, J. T. (2009). Left-right ideological differences in system justification following exposure to complementary versus noncomplementary stereotype exemplars. European Journal of Social Psychology, 39(2) 290-298.

Kay, A. C., Jimenez, M. C., \& Jost, J. T. (2003). Savanyú szôlő, édes citrom és status quo megelôlegezett racionalizációja. In Jost, J. T.: Önalávetés a társadalomban: a rendszerigazolás pszichológiája (198-228). Budapest: Osiris Kiadó.

Kay, A. C., Shepherd, S., Blatz, C. W., Chua, S. N., \& Galinsky, A. D. (2010). For god (or) country: the hydraulic relation between government instability and belief in religious sources of control. Journal of Personality and Social Psychology, 99(5) 725-739.

Kugler, M., Jost, J. T., \& Noorbaloochi, S. (2014). Another look at moral foundations theory: Do authoritarianism and social dominance orientation explain liberal-conservative differences in "moral" intuitions? Social Justice Research, 27(4) 413-431.

Lane, K., \& Jost, J. T. (2011). Black man in the White House: Ideology and implicit racial bias in the age of Obama. In G. S. Parks, M. Hughey (Eds): The Obamas and a (post) racial America? (48-69). New York: Oxford.

Laurin, K., Gaucher, D., \& Kay, A. (2013). Stability and the justification of social inequality. European Journal of Social Psychology, 43(4) 246-254.

Lavine, H., Jost, J. T., \& Lodge, M. (2014). Political cognition and its normative implications for the "democratic experiment": Theory, evidence, and controversy. In E. Borgida, J. Bargh (Eds), APA handbook of personality and social psychology. Vol. 1. (721-752). Washington, DC: APA.

McGuire, W. J. (1998). A poli-pszi kapcsolat: egy hosszú történet három szakasza. In: Hunyady György (szerk.), Történeti és politikai pszichológia (20-44). Budapest: Osiris Kiadó.

McGuire, W. J. (1999). Constructing Social Psychology: Creative and Critical Processes (210-229). Cambridge University Press.

McGuire, W. J. (2001). A gondolatrendszerek dinamikus múködése. In McGuire, W. J.: Makacs nézetek és a meggyôzés dinamikája (209-235). Budapest: Osiris Kiadó.

Napier, J. L., \& Jost, J. T. (2008a). Why are conservatives happier than liberals? Psychological Science, $19(6) 565-572$. 
Napier, J. L., \& Jost, J. T. (2008b). The "anti-democratic personality" revisited: A cross-national investigation of working class authoritarianism. Journal of Social Issues, 64(3) 595-617.

Napier, J. L., Mandisodza, A. N., Andersen, S. M., \& Jost, J. T. (2006). System justification in responding to the poor and displaced in the aftermath of Hurricane Katrina. Analyses of Social Issues and Public Policy, 6(1) 57-73.

Napier, J. L., Thorisdottir, H., \& Jost, J. T. (2010). The joy of sexism? A multinational investigation of hostile and benevolent justifications for gender inequality and their relation to subjective well-being. Sex Roles: A Journal of Research, 62(7-8) 405-419.

Oldmeadow, J., \& Fiske, S.T. (2007). System-justifying ideologies moderate status=competence stereotypes: Roles for belief in a just world and social dominance orientation. European Journal of Social Psychology, 37(6) 1135-1148.

Pliskin, R., Yudkin, D., Jost, J. T., \& Trope, Y. (in press). Myopia of the Masses: Relative Deprivation, Comparative Scope, and System Justification. In Suls, R., Collins, R., Wheeler, L. (Eds), Social comparison in judgement and behavior. New York: Oxford University Press.

Political Psychology 25(6)

Schwarz, N., Wänke, M., \& Bless, H. (1999). A változások szubjektiv felmérése és értékelése: Néhány tanulság a társadalmi kogníció vizsgálatából. In Hunyady György (szerk), Történeti és politikai pszichológia (281-302). Budapest: Osiris Kiadó.

Schyns, P., Nuus, M., \& Dekker, H. (2005). Political cynicism and social cohesion in Europe and the United States. Paper presented at the ISPP conference 'Political psychology facing the real world'. Toronto, Canada, July 3-6.

Sibley, C. G., \& Duckitt, J. (2010). The ideological legitimation of the status quo: Longitudinal tests of a social dominance model. Political Psychology, 31(1) 109-137.

Sidanius, J., \& Pratto, F. (1998). Az elnyomás elkerülhetetlensége és a szociális dominancia dinamikája. In: Hunyady György (szerk.), Történeti és politikai pszichológia (130-164). Budapest: Osiris Kiadó.

Sidanius J, \& Pratto F. (2005). A társadalmi dominancia - A társadalmi hierarchia és elnyomás csoportközi elmélete. Budapest: Osiris Kiadó.

Son Hing, L. S., Bobocel, D. R., Zanna, M. P., Garcia, D. M., Gee, S. S., \& Orazietti, K. (2011). The merit of meritocracy. Journal of personality and social psychology, 101(3) 433-450.

Sterling, J., Jost, J. T., \& Pennycook, G. (2016). Are neoliberals more susceptible to bullshit? Judgment and Decision Making, 11(4) 352-360.

Stern, C., West, T. V., Jost, J. T., \& Rule, N. O. (2014). "Ditto heads": Do conservatives perceive greater consensus within their ranks than liberals? Personality and Social Psychology Bulletin, 40(9) 1162-1177.

Tajfel, H. (1981). Human Groups and Social Categories. Cambridge: Cambridge University Press.

Tajfel, H., \& Turner, J. C. (1979). An integrative theory of integroup conflict. In Austin W. G, Worchel, S. (Eds), The social psychology of intergroup relations (33-47). Monterey. CA: Brooks/ Cole.

Thorisdottir, H., \& Jost, J. T. (2011). Motivated closed-mindedness mediates the effect of threat on political conservatism. Political Psychology, 32(5) 785-811.

Turner, J. C. (1987). Rediscovering the social group. In Turner, J. C., Hogg, A., Oakes, P. S., Reicher, S. D., \& Wetherell, M. S. (Eds), Rediscovering the Social Group: A Self-categorization Theory. (42-67). Oxford: Blackwell.

Tyler, T. R., \& Jost, J. T. (2007). Psychology and the law: Reconciling normative and descriptive accounts of social justice and system legitimacy. In A. W. Kruglanski, \& E. T. Higgins (Eds), Social psychology: Handbook of basic principles. 2nd ed. (807-825). New York: Guilford. 
van der Toorn, J., Berkics, M., \& Jost, J. T. (2010). System justification, satisfaction, and perceptions of fairness and typicality at work: A cross-system comparison involving the U.S. and Hungary. Social Justice Research, 23(2-3) 189-210.

van der Toorn, J., Feinberg, M., Jost, J. T., Kay, A. C., Tyler, T. R., Willer, R., \& Wilmuth, C. (2015). A sense of powerlessness fosters system justification: Implications for the legitimation of authority, hierarchy, and government. Political Psychology, 6(1) 93-110.

van der Toorn, J., \& Jost, J. T. (2014). Twenty years of system justification theory: Introduction to the special issue on "Ideology and system justification processes." Group Processes E् Intergroup Relations. 17(4) 413-419.

van der Toorn, J., Jost, J. T., \& Berkics, M. (2014). Job satisfaction and perceived fairness in Hungary and the USA. In A. C. Michalos (Ed.), Encyclopedia of quality of life and well-being research. Dordrecht, Netherlands: Springer.

van der Toorn, J., Nail, P. R., Liviatan, I., \& Jost, J. T. (2014). My country, right or wrong: Does activating system justification motivation eliminate the liberal-conservative gap in patriotism? Journal of Experimental Social Psychology, 54 50-60.

van der Toorn, J., Tyler, T. R., \& Jost, J. T. (2011). More than fair: Outcome dependence, system justification, and the perceived legitimacy of authority. Journal of Experimental Social Psychology, 47(1) 127-138.

Wakslak, C. J., Jost, J. T., \& Bauer, P. (2011). Spreading rationalization: Increased support for large-scale and small-scale social systems following system threat. Social Cognition, 29(2) 288-302.

\section{SYSTEM JUSTIFICATION AND SYSTEM CRITICISM}

\section{HUNYADY, GYÖRGY}

System justification, the system supporting attitude of masses of people at the bottom of the hierarchy and their legitimization of the social relations that are detrimental to them is a priority topic of fundamental social psychological theories studying cognition and emotions related to, reflecting, and shaping social systems. Rich empirical data gathered from around the advanced world support John Jost's elaborate theory. In contrast, system criticism not only appears next to system justification in the public thinking of the post-communist region (including Hungary), but may even prevail. Our last fifteen years of investigations on stereotypes, attitudes, values, and social public feelings (including studies on 8 national representative samples) give an exact description of the ambivalence of system criticism and system justification in present-day Hungarian thinking: dissatisfaction arising basically from the lack of social security, moral social criticism, and increased demand for democracy, as opposed to the appreciation of the economic-political situation and support for the centralization of power. It is characteristic of the Hungarian public affairs that the dominant system criticism is associated with pessimism for the future, and the subdominant system justification correlates with optimism for the future. In addition to the historical-cultural interpretation of the differences in the international trends, the present paper offers suggestions for the further elaboration of the System Justification Theory (considering the ambivalence of system attitudes, the differences across systems, the context of system-images, and the perceived probabilities of prospects). The present research introduced and used a so called Counterselection Scale System for the study of public feelings derived from the views on society, and a Democracy Attitude measuring tool, encompassing 3 subscales.

Keywords: system justification, system criticism, counterselection scale system, democracy attitude measurement, public feeling in Hungary, system attitudes in historical context 